\title{
Influence of the Tumor Microenvironment on NK Cell Function in Solid Tumors
}

\author{
Ombretta Melaiu ${ }^{1,2 \dagger}$, Valeria Lucarini ${ }^{1 \dagger}$, Loredana Cifaldi ${ }^{3 *}$ and Doriana Fruci ${ }^{1 *}$ \\ ${ }^{1}$ Paediatric Haematology/Oncology Department, Ospedale Pediatrico Bambino Gesù, Rome, Italy, ${ }^{2}$ Department of Biology, \\ University of Pisa, Pisa, Italy, ${ }^{3}$ Academic Department of Pediatrics (DPUO), Ospedale Pediatrico Bambino Gesù, Rome, Italy
}

OPEN ACCESS

Edited by: Anahid Jewett, University of California, Los Angeles, United States

Reviewed by:

Robin Parihar, Baylor College of Medicine United States

Robert J. Canter, University of California, Davis, United States

*Correspondence:

Loredana Cifaldi loredana.cifaldi@opbg.net Doriana Fruci

doriana.fruci@opbg.net

†These authors have contributed equally to this work

Specialty section:

This article was submitted to

Cancer Immunity and Immunotherapy,

a section of the journal

Frontiers in Immunology

Received: 13 August 2019 Accepted: 11 December 2019

Published: 21 January 2020

Citation:

Melaiu O, Lucarini V, Cifaldi L and Fruci D (2020) Influence of the Tumor

Microenvironment on NK Cell Function in Solid Tumors.

Front. Immunol. 10:3038.

doi: 10.3389/fimmu.2019.03038
Natural killer (NK) cells are a population of innate lymphoid cells playing a pivotal role in host immune responses against infection and tumor growth. These cells have a powerful cytotoxic activity orchestrated by an intricate network of inhibitory and activating signals. The importance of NK cells in controlling tumor growth and in mediating a robust anti-metastatic effect has been demonstrated in different experimental mouse cancer models. Consistently, high density of tumor-infiltrating NK cells has been linked with a good prognosis in multiple human solid tumors. However, there are also tumors that appear to be refractory to NK cell-mediated killing for the presence of an immunosuppressive microenvironment affecting NK cell function. Immunotherapeutic strategies aimed at restoring and increasing the cytotoxic activity of NK cells in solid tumors, including the adoptive transfer of NK and CAR-NK cells, are currently employed in preclinical and clinical studies. In this review, we outline recent advances supporting the direct role of NK cells in controlling expansion of solid tumors and their prognostic value in human cancers. We summarize the mechanisms adopted by cancer cells and the tumor microenvironment to affect NK cell function, and finally we evaluate current strategies to augment the antitumor function of NK cells for the treatment of solid tumors.

\footnotetext{
Keywords: natural killer cells, tumor microenvironment, solid tumors, immune checkpoint inhibitors, cellular metabolism, cancer stem cells, hypoxia, adoptive transfer of NK and CAR-NK cells
}

\section{INTRODUCTION}

Natural killer (NK) cells are a specialized population of innate lymphoid cells (ILCs) that mediates cytotoxic functions against damaged, infected, and pre-malignant cells through an intricate network of signals that allow for rapid activation (1). NK cell cytotoxicity is mainly regulated by the secretion of effector molecules (IFN- $\gamma$, TNF- $\alpha$, NO, IL-2, IL-12, IL-15, IL-18, and IL-21), and the interplay between inhibitory and activating signals originating at the cell surface from NK cell-inhibitory receptors (NK-IRs) and NK cell-activating receptors (NK-ARs), respectively. NK-IRs promote the effector function upon interaction with ligands expressed on normal and healthy cells. Conversely, NK-ARs recognize ligands encoded by pathogens (2), or induced by cellular stress during viral infections (3), or cellular growth factors (4). The downregulation of inhibitory ligands and the expression of ligands for NK-ARs on cancer cells can trigger NK cells to kill them and secrete cytokines, such as IFN- $\gamma$ and TNF- $\alpha$. Thus, blocking interaction between NK-IRs and their ligands or enhancing NK-ARs-ligand binding may represent a promising strategy to generate an antitumor activity. 
NK cells in the peripheral blood, spleen, and bone marrow can infiltrate other tissues. In human, two distinct subsets of NK cells have been identified based on CD56 expression levels. The CD56 $6^{\text {bright }}$ NK cell subset, representing the majority of NK cells in the peripheral blood, is specialized in the secretion of cytokines and chemokines in response to IL-12, IL-15, and IL-18, and in the regulation of adaptive immunity. The CD $56^{\mathrm{dim}} \mathrm{NK}$ cell subset is both cytotoxic and cytokine-producing and expresses high levels of CD16 (also known as Fc $\gamma$ RIII), which is responsible for antibody-dependent cellular cytotoxicity (ADCC). The recruitment of NK cells in the inflamed tissues is regulated by the expression of several chemokine receptors, including CXCR3 that binds to the tumor-derived chemokine ligands CXCL9, CXCL10, and CXCL11 (5). Although the presence of tumor-infiltrating NK cells confers a favorable outcome in many tumors, in others, their function is impaired by soluble modulators secreted in the tumor microenvironment (TME). In this Review, we discuss recent evidence for a direct role of NK cells in controlling tumor expansions and summarize the mechanisms adopted by tumor cells and the TME to affect NK cell functions in solid tumors. Finally, we evaluate novel therapeutic strategies to enhance the antitumor function of NK cells for the treatment of solid tumors.

\section{ROLE OF NK CELLS IN THE IMMUNOSURVEILLANCE OF SOLID TUMORS}

NK cells control tumor growth by interacting directly with tumor cells or affecting the function of other populations of innate and adaptive immunity in the TME. The importance of NK cells in antitumor immunity has been established in different experimental mouse tumor models.

Depletion of NK cell populations prior to tumor transplantation has been shown to cause a more aggressive phenotype with metastatic tumors (6-8). Specifically, the use of mutant mice with developmental and functional alterations of NK cells allowed a better understanding of the role of these cells in antitumor immunity. NCR1/NKp46 is directly involved in the killing of melanoma and Lewis lung carcinoma cells and in the formation of metastases (9). Indeed, $\mathrm{NCR}^{-/-}$mice underwent a more aggressive tumor development compared to wild type (WT) mice. Mice knockout for Mcl1, which is required to sustain the in vivo survival of NK cells, were characterized by the total absence of NK cells and a rapid development of metastatic melanomas (10). A similar observation was reported in IL-2rg ${ }^{-/-}$and TLR3 ${ }^{-/-}$mice $(11,12)$. TLR3 is known to limit B16F10 lung metastasis through the production of IFN- $\gamma$ by NK cells. The lack of TLR3 signaling downregulates NK cell function following cytokine stimulation, leading to defective immune responses unable to constrain metastatic diseases (12). DNAM-1 ${ }^{-/}$mice developed fibrosarcoma and papilloma in response to chemical carcinogens significantly more frequently than WT mice (13). Tbx21, also known as T-bet, is a transcription factor involved in the differentiation of NK cells. Tbx $21^{-/-}$mice injected intravenously with melanoma or colorectal carcinoma cells were more susceptible to metastasis formation compared to WT mice (14). The ability of NK cells to invade the primary tumors and migrate in the metastatic site is dependent on the heparanase. Mice lacking heparanase specifically in NK cells (Hpse ${ }^{\mathrm{fl} / \mathrm{fl}} \mathrm{NKp} 46^{-\mathrm{iCre}}$ mice) were more susceptible to develop lymphoma, metastatic melanoma, prostate carcinoma, or mammary carcinoma when challenged with the carcinogen methylcholanthrene (15). These observations suggest that NK cells play a prominent role in controlling tumor growth and in mediating a robust anti-metastatic effect.

Further evidence for the role of NK cells in controlling tumor development and dissemination derived from the ability of these cells to target and eliminate cancer stem cells (CSCs), a subset of cells with self-renewal ability involved in the generation and evolution of tumors (16). CSCs exhibit a typical surface expression profile consisting of low levels of MHC class I, CD54 and PD-L1, and high expression of CD44 (17). The susceptibility of CSCs to NK cell-mediated killing has been reported in different tumor models $(18,19)$. An in vivo study reveals that activated NK cells transferred in NSG mice harboring orthotopic pancreatic cancer xenografts were able to preferentially kill CSCs, leading to a significant reduction of both intratumoral CSCs and tumor burden (20). Additionally, in colorectal cancer, CSCs upregulated the NK-ARs NKp30 and NKp44 and were susceptible to NK cell-mediated killing (19). Similarly, glioblastoma-derived CSCs showed an increased susceptibility to NK cell killing by both allogeneic and autologous IL-2 and IL-15 activated NK cells (21). Melanoma cell lines with CSC features exposed to IL-2-activated allogeneic NK cells showed an increased susceptibility to NK cellmediated killing through upregulation of the DNAM-1 ligands, such as PVR and Nectin-2 (22). Breast cancer CSCs showed sensibility to IL-2- and IL-15-treated NK cells and increased expression of NKG2D ligands, such as ULBP1, ULBP2, and MICA (23).

CSCs are also considered an important source of resistance to standard anti-cancer therapies. Following chemotherapy and radiation therapy treatments, CSCs upregulate ligands for NKG2D such as MICA and MICB, resulting in an increase of NK cell cytotoxicity $(24,25)$.

NK cells are able to target and shape CSC-undifferentiated tumors, thereby leading to a selection of a differentiated tumor subset (26). After selection, NK cells down-modulate their surface receptors, lose their cytotoxicity, and become anergized, but continue to produce IFN- $\gamma$ and TNF- $\alpha$, which drive differentiation of the remaining stem cells. This results in an increased expression of MHC class I, CD54, and PD-L1 and reduction of CD44 on CSC surface. These cells exhibit a decreased proliferation rate, inability to invade or metastatize and increased susceptibility to chemotherapeutic and radiotherapeutic agents $(26,27)$.

Despite the role of NK cells in targeting CSC/undifferentiated tumors, some authors have highlighted an association between the stage of differentiation and sensitivity to NK cell-mediated cytotoxicity. Studies conducted on patients with pancreatic tumors or oral squamous carcinoma stem cells revealed that although CSCs/undifferentiated tumors were susceptible to NK cell-mediated cytotoxicity, they remained significantly resistant to chemotherapeutic and radiotherapeutic agents. Conversely, 
differentiated tumors grew slower and were resistant to primary NK cell-mediated cytotoxicity with high susceptibility to chemotherapeutic and radiotherapeutic agents $(27,28)$.

The role of NK cells in controlling tumor growth is also supported by several evidence in human specimens. The first studies date back to the late 1980s (29-31). Several authors have studied the phenotype of circulating NK cells and their cytotoxic activity in cancer patients compared to healthy donors (32). Other authors have investigated the prognostic role of tumor-infiltrating NK cells (33), but due to the lack of immunohistochemical markers that unambiguously identify NK cells, current information is limited. Different methods are used to attribute a prognostic value to specific immune cell subsets. The most reliable is the one that evaluates survival analysis stratifying the subjects according to the median cutoff value for density of immune cell subsets.

Denkert et al. showed that a higher density of NK cells is an indicator of good prognosis in breast cancer (33). A pooled analysis of 3,771 patients treated with neoadjuvant therapy revealed the presence of intratumoral immune cell types, including NK cells, significantly associated with better prognosis of HER2-positive and triple negative breast cancer patients (33). Trastuzumab treatment was associated with a significant increase of tumor-infiltrating NK cells and expression of granzyme B and TiA1 in breast cancer compared with controls (34). Moreover, the expression of NCR1 and other NK cell-associated genes, i.e., CD1d, DNAM-1, CRTAM, CD96, and NCR3/NKp30, was associated with prolonged disease-free survival (DFS) of breast cancer patients (34). High number of intratumoral NK cells was considered an optimal biomarker of response to the antiHER2 antibody-based treatment. Indeed, the presence of these cells was significantly associated with a complete response and extended DFS (35). The same authors showed that the number of circulating $\mathrm{CD}_{57}{ }^{+} \mathrm{NK}$ cells was inversely correlated to tumorinfiltrating NK cells and predicted resistance to HER2-specific antibody treatment in HER2-positive primary breast cancers (36). From a clinical perspective, baseline screening for high circulating $\mathrm{CD}_{57}{ }^{+} \mathrm{NK}$ cells could be implemented for the identification of patients with primary resistance to neoadjuvant treatment with HER2 therapeutic antibodies, complementing the positive predictive value of tumor-infiltrating NK cells in diagnostic biopsies (27).

Melanoma patients were characterized by expansion of CD56 ${ }^{\text {dim }} \mathrm{CD} 57^{\mathrm{dim}} \mathrm{CD} 69^{+} \mathrm{CCR}^{+} \mathrm{KIR}^{+}$tumor-infiltrated $\mathrm{NK}$ cells (37). These cells showed robust cytotoxicity against autologous tumor cells compared to those derived from tumorfree ipsilateral lymph nodes of the same patients (37). Melanoma cells isolated from metastatic lymph nodes were efficiently lysed by circulating NK cells expressing high levels of NKG2D, NKp30, DNAM-1, and CD62L (38).

Recently, the prognostic role of NK cells has been investigated through the expression of genes specific for NK cell function. NK cell gene signatures were associated with a strong survival advantage for metastatic melanomas (39). More recently, Barry et al. defined a clear link between NK cells and dendritic cells (DC), demonstrating that NK cells produce FLT3LG cytokine that controls the intratumoral level of BDCA-3 ${ }^{+}$DCs. The authors also showed that the high expression of NK and DC gene signatures was associated with a better OS in two independent datasets of melanoma patients (40).

High levels of tumor-infiltrating NK cells have been associated with a good prognosis also in other human cancers, including gastrointestinal stromal tumor (41-43), neuroblastoma (44), head and neck cancer (45), and prostate cancer (46). A more complex and heterogeneous landscape has been outlined for other types of neoplasms. A gene signature able to predict tissue NK cell content and prognosis of renal cell carcinoma patients was proposed (47). Two distinct groups of renal cancer patients have been identified based on the level of tumor-infiltrating NK cells (48). In both groups, NK cells were not cytolytic but differed for CD16 expression levels. NK cells from tumors with high NK cell content ( $>20 \%$ of the lymphocyte population) were CD16 $6^{\text {bright }}$, whereas those from tumors with low NK cell content $(<20 \%)$ were CD56 ${ }^{\mathrm{dim}}$. In vitro experiments showed that unlike the low-NK group, the high-NK group was able to acquire cytotoxic function against K562 cells (48). An early study reported that low NK cell cytotoxicity was predictive of colon cancer recurrence, independently of other prognostic factors (30). These data were confirmed in patients with metastatic colorectal cancer treated with the mAb 17-1A (49). Recently, density and tissue distribution of NK cells were investigated in 112 primary colorectal cancer samples (50). Despite high concentration of chemokines known to promote NK cell infiltration, colorectal cancers were only scarcely infiltrated by these cells as compared to normal mucosa, thus suggesting the presence of soluble factors in the TME preventing NK cell infiltration.

The tissue distribution of NK cells was studied in different subtypes of lung cancer. A high number of intratumoral $\mathrm{CD} 7^{+} \mathrm{NK}$ cells, as evaluated by IHC analysis, was significantly associated with a better clinical outcome in squamous cell lung cancer patients (51). A gene expression study conducted on 148 blood samples discovered valid prognostic innate immune markers (52). Among the screened genes, the enhanced expression of NCR3 was associated with better overall survival (OS) in non-small cell lung cancer patients. More recently, a low number of circulating NKp46 ${ }^{+} \mathrm{CD} 56^{\mathrm{dim}} \mathrm{CD} 16^{+} \mathrm{NK}$ cells was significantly associated with a better OS in small cell lung cancer patients. Intratumoral NK cells were less cytotoxic in non-small cell lung cancer patients, as compared to circulating NK cells or those derived from normal lung tissues (53). Of note, NK cells were located in the tumor stroma not in direct contact with cancer cells. Further evidence indicate that NK cells are very rare within human non-small cell lung cancer and that those infiltrating tumor tissues resemble the circulating CD56 ${ }^{\text {bright }}$ NK cells (54). More recently, Lavin et al. found that NK cells are the least abundant immune cell population within lung adenocarcinomas and that those expressing CD16 are dramatically reduced in tumors as compared to normal tissues (55). This subset of NK cells is less cytotoxic, expressing low levels of granzyme B, IFN- $\gamma$, and CD57.

A reduced number of $\mathrm{CD} 56^{\mathrm{dim}} \mathrm{CD} 16^{\text {high }} \mathrm{NK}$ cells was detected in the liver tumor area as compared to non-neoplastic area (56). These cells also showed an impaired cytotoxic ability. In general, high density of NK cells within intratumoral region of hepatocellular carcinoma showed better OS and DFS. Conversely, 
the few NK cells infiltrating advanced hepatocellular carcinoma exhibited attenuated capacities for cytokine productions. These evidence indicate that infiltration of functional NK cells in hepatocellular carcinoma tissues may represent the host reaction to cancer and that TME impairs NK cell function during disease progression (57).

Recently, a new subset of liver-resident NK cells characterized for expression of CD49a has been discovered (58). These cells are abundant in the peritumoral area of hepatocellular carcinoma and are characterized by the expression of PD1, CD96, and TIGIT. The accumulation of these cells in liver tumors was correlated with poor prognosis, thus suggesting a role of this NK cell subset in the hepatocellular carcinoma development (58).

In prostate cancer, a strong immunosuppressive microenvironment impairs $\mathrm{NK}$ cell function at multiple levels. Indeed, NK cells that infiltrated the cancer prostate tissues were mainly $\mathrm{CD}_{5}{ }^{+}$and displayed an immature, but activated phenotype with low or no cytotoxic potential. The authors found that TGF- $\beta$ is highly secreted into the TME and provided an immunosuppressive effect on NK cells. Co-culture experiments revealed that tumor cells induced expression of inhibitory receptors downregulating that of the activating receptors NKp46, NKG2D, and CD16 on NK cells, thus preventing their recognition (46). Similarly, endometrial cancer was poorly infiltrated by NK cells. These cells, when present, expressed coinhibitory molecules, such as TIGIT and TIM-3, proportionally with the severity of the disease, thus suggesting an important role of the TME in reducing recruitment of functional NK cells to the tumor site (59).

Overall, many evidences indicate that NK cells, although representing an extremely rare subset of immune cells, are able to invade some solid tumors and, when functionally activated, are associated with good prognosis. However, in several cases, the picture is much more complex, with contradictory results, and no or negative effects on patient's prognosis. Different factors contribute to attenuate the antitumoral properties of NK cells, thus providing the need to integrate the study of NK cell density, with equally important elements including phenotype and localization with respect to stroma and parenchyma tumor cells and other immune cell populations. Discordant results obtained in certain tumors could be derived from the methods used to unequivocally identify NK cells, the type of tissue, or the tumor phase (60). The inability of NK cells to limit tumor growth and improve patient survival may result from the presence of an immunosuppressive TME. Indeed, TME renders solid tumors particularly refractory to NK cell killing through a plethora of strategies ranging from preventing the recruitment of intratumoral NK cells, to confining them, when present, to the stromal part of the tissue, or rather attract the recruitment of noncytotoxic NK cells (CD56 ${ }^{\text {bright }} \mathrm{CD} 16^{\text {low/neg }}$ ) in the tumor bed.

\section{IMMUNOSUPPRESSIVE PROPERTIES OF THE TME ON NK CELLS}

TME, composed of cancer cells, fibroblasts, endothelial cells, and immune cells, provides conditions that promote tumor progression. Accumulating evidences indicate that TME produced soluble modulators that negatively regulate maturation, proliferation, and effector function of NK cells (Figure 1). These immunosuppressive factors may act either directly on NK cells or indirectly by stimulating other immune cells, such as antigen-presenting cells (APC), regulatory T cells (Tregs), and myeloid-derived suppressor cells (MDSC), to produce additional immunosuppressive molecules.

TGF- $\beta$ is a cytokine produced in the TME by tumor cells, Tregs, MDSCs, and other stromal cells. This cytokine is known to inhibit both the expansion and function of effector cells and to promote the proliferation of Tregs (61). TGF- $\beta$ impairs NK cell function directly or indirectly by cell-cell contact between NK and other cytokine-producing cells $(62,63)$. As a direct effect, TGF- $\beta$ limits NK cell cytotoxicity and IFN- $\gamma$ production by inhibiting the T-bet transcription factor (SMAD3) (64) and downregulating the expression of NKp30 and NKG2D, and its ligand MICA in cancer patients (65-67). In colorectal cancer and lung cancer, downregulation of NKG2D has been associated with increased serum levels of TGF- $\beta$ (68). The levels of DNAX activating protein $12 \mathrm{kDa}$ (DAP12), a crucial signaling adaptor of NKG2D in human NK cells, were downregulated by TGF$\beta$-induced miR-183 (69). In an orthotopic liver cancer model, TGF- $\beta$ was shown to bind on the cell surface of MDSCs and inhibits NK cell function (70). TGF- $\beta$ is also able to inhibit NK cell function by targeting the serine and threonine kinase mTOR, a crucial signaling integrator of pro- and antiinflammatory cytokines, such as interleukin-15 (IL-15), in both murine and human NK cells (71). Interestingly, TGF- $\beta$ is able to transdifferentiate NK cells into ILC type 1 (ILC1), which are missing of cytotoxic functions $(72,73)$. TGF- $\beta$ is also able to dampen $\mathrm{CD} 56^{\mathrm{dim}}$ recruitment and favor that of CD56 $6^{\text {bright }}$ (74). It contributes to modulate chemokine repertoire reducing the expression of those attracting CD56 ${ }^{\mathrm{dim}} \mathrm{NK}$ cells (CXCL2, CX3CL1, CXCL1, and CXCL8), and increasing that of chemokines (CXCL9, CXCL10, CXCL19, and CCL5), driving migration of CD56 $6^{\text {bright }} \mathrm{NK}$ cells $(60,74)$. In ovarian $(75)$ and lung (76) cancer patients, CD $56^{\text {bright }} / \mathrm{CD} 16^{\text {low }}$ represents the predominant NK cell population in the TME. Moreover, the presence of intratumoral tertiary lymphoid structures (TLS) in lung cancer drives the expression of chemokines normally secreted in secondary lymphoid organs (CCL19, CCL21, etc.), thus preferentially attracting non-cytotoxic CD56 ${ }^{\text {bright }} \mathrm{NK}$ cells at the tumor site (76). Based on these findings, TGF- $\beta$ may be considered a target for enhancing NK cell-mediated antitumor immunity. Currently, inhibition of TGF- $\beta$ signaling in preclinical studies (77-83), including those based on the combined use of immune checkpoint inhibitors, such as anti-PD-L1 (84-86), as well as in clinical trials (87-89), represents a promising antitumor approach supported mainly by the analysis on $\mathrm{CD}^{+} \mathrm{T}$ cells. Interestingly, the use of anti-TGF- $\beta$ in solid tumors allows the accumulation of NK cells, the increased production of IFN- $\gamma$, and the restoration of NKG2D (90).

Another crucial factor leading to dysfunctional NK cells in cancer is the impaired cellular metabolism (91-93). TME is known to be very poor in nutrients, such as glucose and glutamine, very important for NK cells (94-97). While 


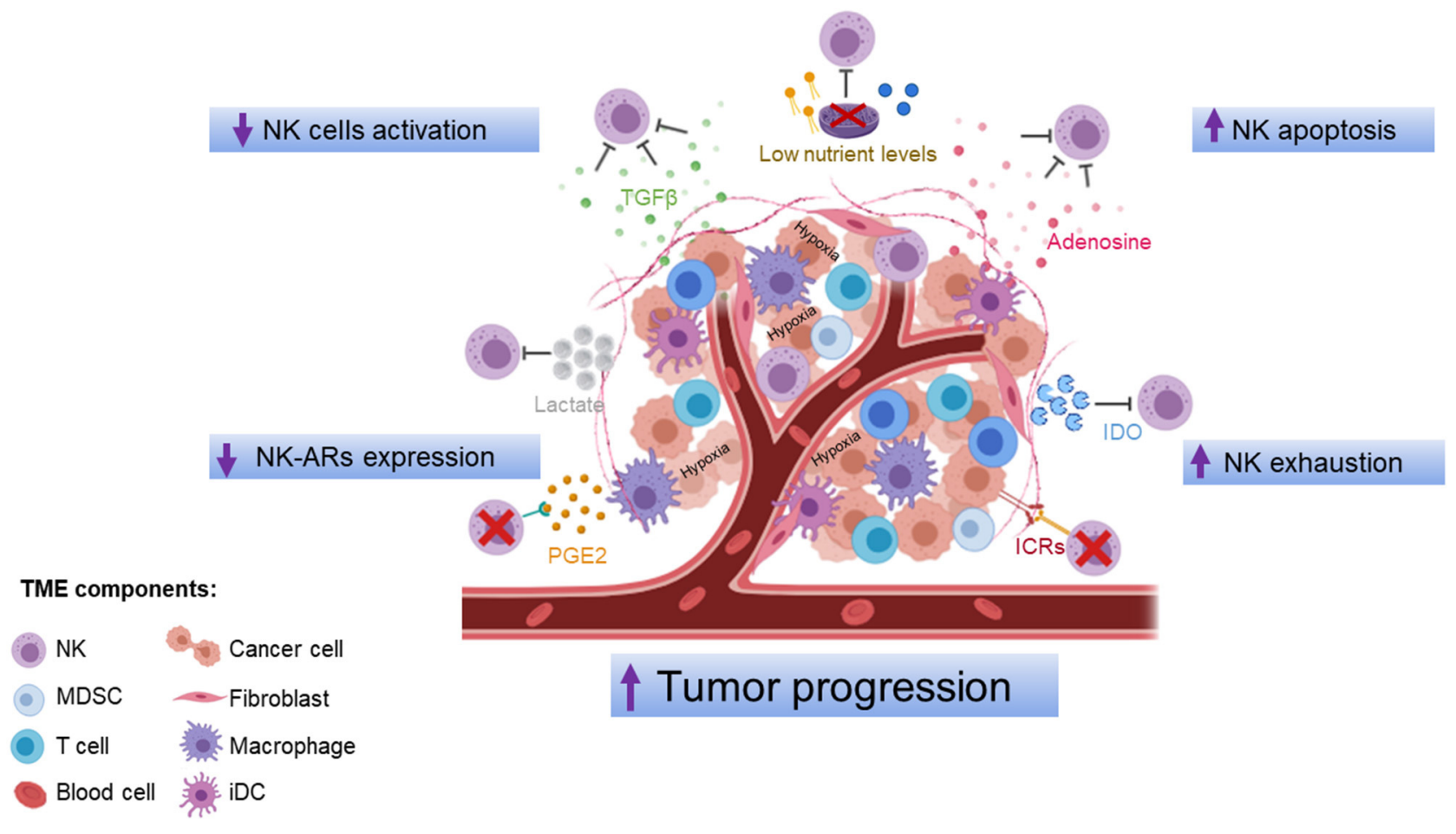

FIGURE 1 | Mechanisms of NK cell dysfunction in the tumor microenvironment. The tumor microenvironment inhibits NK cell function via production of soluble modulators, low nutrient levels, and hypoxic conditions that negatively regulate maturation, proliferation, activation, and effector function of NK cells. ICRs, immune-checkpoint receptors; IDO, indoleamine 2,3-dioxygenase; PGE2, prostaglandin E2; TGF- $\beta$, transforming growth factor- $\beta$; iDC, intratumoral dendritic cells; MDSC, myeloid-derived suppressor cells; NK, natural killer cells. The figure was performed with https://biorender.com/.

much attention has been focused on $\mathrm{T}$ cells and macrophages (98-101), little is known about the NK cell metabolism. In humans, increased glycolysis and oxidate phosphorylation (OXPHOS) stimulate CD56 ${ }^{\text {bright }} \mathrm{NK}$ cells to produce IFN- $\gamma$ (102). In mice, steady-state NK cells favor OXPHOS, rather than glycolysis, as the primary metabolic pathway. Conversely, activated NK cells induced by IL-2/IL-12 have a greater preference for glycolysis. Glycolysis is an important metabolic process for NK cell function, and in general, it is increased in activated NK cells. A recent study showed that lung tumors upregulate the expression of the gluconeogenesis enzyme fructose bisphosphatase 1 (FBP1) in tumor-infiltrating NK cells through a mechanism involving TGF- $\beta$ (92). This leads to NK cell dysfunction by inhibiting both glycolysis and the viability of NK cells. The authors showed that pharmacological inhibition of FBP1 can revert the dysfunctional phenotype of NK cells during tumor promotion, but not during tumor progression. Indeed, similarly to tumor-infiltrating T cells $(103,104)$, NK cells in the mouse lung cancer are functional during tumor initiation, while assume a mild dysfunctional state during tumor promotion that can be reverted by pharmacological FBP1 inhibition. Subsequently, NK cells evolve into an irreversible dysfunctional state that can no longer be rescued by FBP1 inhibition (93). Other molecules that can potentially inhibit NK cell metabolism include two physiological products of enzymatic cholesterol oxidation, 25-hydroxycholesterol and 27-hydroxycholesterol, that inhibit the activation of SREBP transcription factors, key regulators of NK cell metabolism (105107). Further evidence supporting the role of the impaired cellular metabolism in leading to dysfunctional NK cells come from studies on obesity in human and murine models. NK cells from obese mice and humans are less responsive to tumor target cells in terms of cytotoxicity and production of IFN- $\gamma$, granzyme B, and perforin (108). This is because NK cells fail to engage a metabolic response when stimulated with cytokines and have reduced metabolic rates, compared to lean counterparts (108). This metabolic dysfunction has been linked to peroxisome proliferator-activated receptor (PPAR)driven lipid accumulation in NK cells leading to altered gene expression, downregulation of mTORC1 and MYC signaling, and decreased rates of glycolysis and OXPHOS (108). NK cells from obese mice and humans fail to kill tumor cells for their inability to form synapses with them, an event that is highly energy consuming (108).

The production of prostaglandin E2 (PGE2) in the TME is another mechanism adopted by tumors to selectively suppress the effector function of NK cells (109-112). PGE2 produced by tumor cells, tumor-associated macrophages, and stromal cells (113-115) represents a key regulator of the NK cell activity for mesenchymal stem cell (MSC)-mediated regulation of NK cell activity (116), tumor-derived MSCs (T-MSCs) (117), and MDSCs (118). In addition, PGE2 produced by 
the thyroid cancer cell microenvironment suppresses NK cell cytotoxicity (119). PGE2 downregulates the expression of NKp30, NKp44, NKp46, and NKG2D by binding to Eprostanoid 2 (EP2) and EP4 receptors on NK cells (112), via a common cAMP-PKA signaling (120), thus resulting in the inhibition of cytotoxicity $(116,121)$. In PGE2-producing tumors, NK cells were less abundant and impaired in their ability to produce cytokines CCL5 and CXCL1 (109). Preclinical studies show that the blocking of PGE2 in a murine model of metastatic breast cancer (122) and in human gastric cancer cells (123) restores NK cell function against tumor. Consistently, the efficacy of celecoxib, a cyclooxygenase2 (COX2) inhibitor able to blockade PGE2 signaling, has been demonstrated in several clinical studies in many solid tumors (https://ClinicalTrials.gov).

The intracellular enzyme indoleamine 2,3-dioxygenase (IDO) is a critical regulator of the TME converting tryptophan into a number of metabolites with immunosuppressive function, including L-Kynurenine (124). IDO overexpression was associated with tumor progression and growth arrest of tumor-infiltrating NK cells $(124,125)$. L-Kynurenine is known to affect NK cell activity by interfering with the IL2-driven upregulation of NKp46 and NKG2D (126). The simultaneous use of PGE2 and IDO inhibitors completely restored NK cell proliferation (116). The NK cell-mediated IFN- $\gamma$ production in response to leukemic cells upregulates IDO, rendering tumor cells more resistant to NK cell-mediated killing (127).

Adenosine, a purine metabolite present at high concentration in the TME, also acts by limiting the activity of protective immune infiltrates, including NK cells, and enhancing that of Tregs and MDSCs (128). Adenosine accumulated in the TME by CD39 and CD73, causing inhibition of tumor-infiltrating NK cells by binding to the purinergic adenosine $A_{2 A}$ receptor expressed on cell surface (129-133). Reduction of adenosine by blocking both CD73 and the $\mathrm{A}_{2 \mathrm{~A}}$ receptor was shown to affect tumor growth and promote recruitment of tumor-infiltrating NK cells (134).

Another factor causing dysfunction of tumor-infiltrating NK cells is hypoxia. Hypoxia downregulates NKp46, NKp30, NKp44, NKG2D, perforin, and granzyme B (135-138). Treatment with IL-2 restores NK cell cytotoxicity in multiple myeloma by increasing NKG2D expression (139).

Tumor cells secrete a large amount of lactate in the TME, causing acidosis and immunosuppression (140). Lactate accumulation has been associated with reduced NK cell cytotoxicity and downregulation of NKp46 (141, 142). The acidification of the TME has been shown to induce apoptosis of liver-resident NK cells in colorectal cancer liver metastases (143). The neutralization of the TME restored the cytotoxic activity of NK cells enhancing NKG2D expression (144).

Additionally, NK cells may express a wide range of immune checkpoint receptors that inhibit their function, including KIRs, CD94/NKG2A, PD1, CTLA4, TIM3, TIGIT, CD96, KLRG-1, LAG3, and, recently discovered, IL-1R8 (145). The effect of these immune checkpoint molecules on NK cell function has been reviewed $(146,147)$.

\section{NK CELL-BASED THERAPEUTIC STRATEGIES TO OVERCOME RESISTANCE IN SOLID TUMORS}

NK cell-based immunotherapy has been successfully applied for hematological malignancies and represents an attractive strategy even for treating solid tumors (148). The therapeutic approaches currently adopted are reported below.

\section{Use of Cytokines, Monoclonal Antibodies, and Immune Checkpoint Inhibitors}

Therapeutic use of cytokines such as IL-12 and IL-18 in supporting ADCC (149-151), or IL-15 and IL-21 in triggering NK cell proliferation, NK-ARs induction, and cytokine production (152-156), resulted effective in increasing NK cell cytotoxicity against solid tumors. The cytokine agonists designed to improve the biological and pharmacokinetic activities of classical cytokines, including IL-15 superagonist ALT-803, showed promising results in both pre-clinical $(157,158)$ and clinical studies (159-161) (Table 1). Interestingly, encouraging results were obtained in combination with anticancer drugs, immune checkpoint inhibitors or vaccines, in terms of increased levels of circulating CD56 $6^{\text {bright }} \mathrm{NK}$ cells in ALT-803-treated patients.

The secretion of ligands for NK-ARs by solid tumor cells has been associated to immune suppressive effects (162). In a murine model, the neutralization of soluble NKG2D ligands such as MICA and MICB with mAb B10G5 was effective against prostate carcinoma and metastasis, leading to the enhanced NK cell infiltration in the tumor parenchyma (163), and improving CTLA-4 blockade therapy (164).

Another approach to sensitize solid tumors to NK cellmediated lysis is to improve ADCC with monoclonal antibodies (mAbs) specific for tumor antigens. Several clinical trials exploring the efficacy of various mAbs targeting tumor antigens are in phase I and II (Table 1). This therapeutic approach is very promising even in challenging pediatric tumors, such as neuroblastoma, in which amplification of the MYCN oncogene, clinically associated with poor prognosis, has been correlated with the reduced tumor susceptibility to NK cell-mediated killing (165).

The adoption of the chimeric mAb Ch14.18 recognizing the main tumor antigen GD2 on neuroblastoma cells was very successful (166) and presently under investigation in several clinical trials in combination with immune checkpoint inhibitors or in the form of chimeric antigen receptors (CARs) for both CAR-T (167) and CAR-NK cells (Table 1).

On the other hand, several approaches aimed to dampen the NK cell-inhibitory signals, such as those mediated by immune checkpoint molecules, have been explored, thus triggering directly immune effector functions including those mediated by NK cells. The initial adoption of anti-KIRs reported very few positive results (168), with potential benefits when used in combination with anti-PD1 for the cure of non-small cell lung cancer patients (169). Blocking of PD1/PD-L1 signaling enhances the production of cytokines and degranulation of 
TABLE 1 | Some selected and most recent clinical trials (since January 1st 2016) on NK cell-based immunotherapies, in different forms of solid tumors, by using cytokines, monoclonal antibodies (mAbs), and immune checkpoint inhibitors.

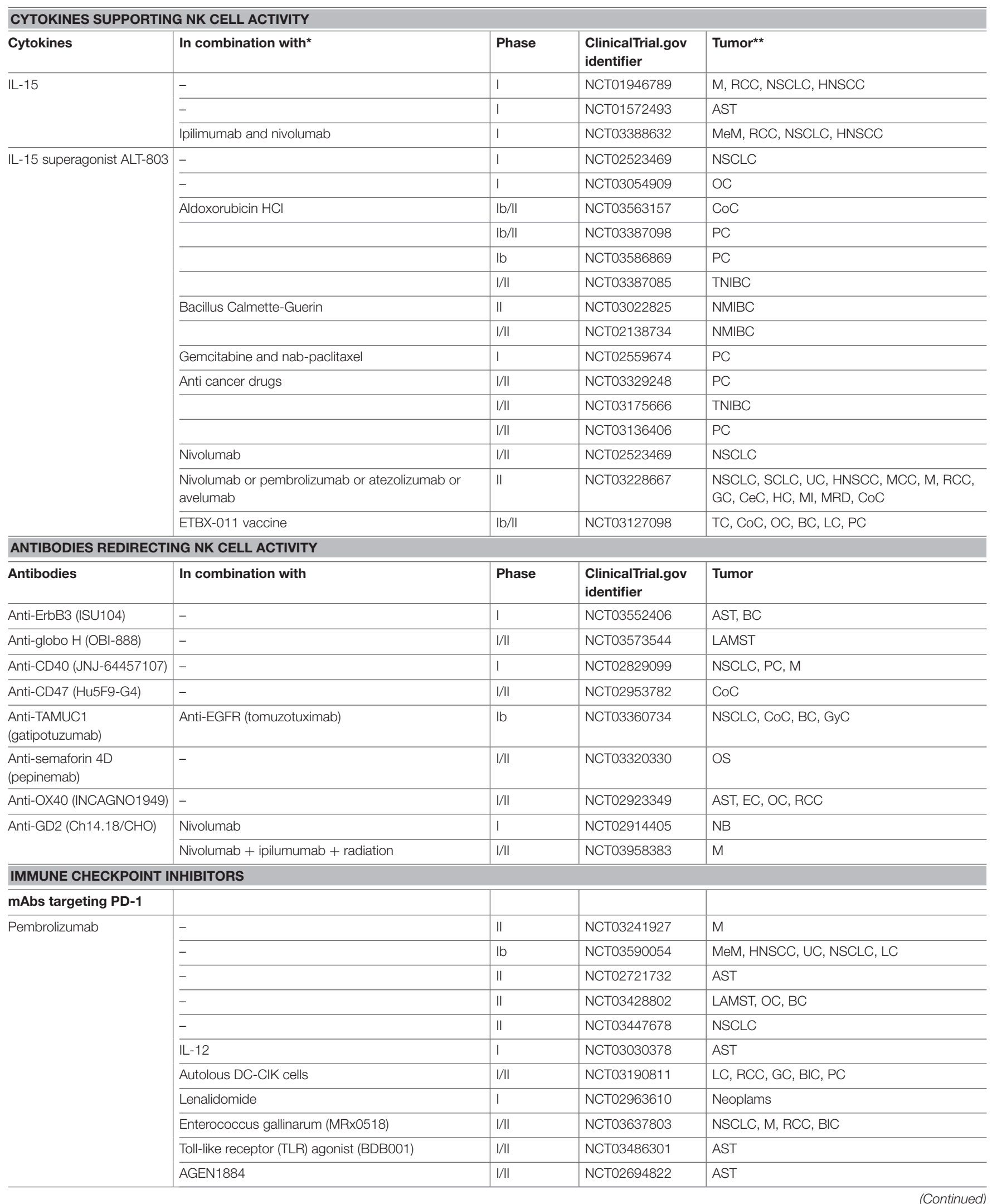


TABLE 1 | Continued

\begin{tabular}{|c|c|c|c|c|}
\hline Antibodies & In combination with & Phase & $\begin{array}{l}\text { ClinicalTrial.gov } \\
\text { identifier }\end{array}$ & Tumor \\
\hline & Nab-paclitaxel + anti cancer drugs & II & NCT03289819 & $\mathrm{BC}$ \\
\hline & TLR9 agonist (AST-008) & $1 / 11$ & NCT03684785 & MeM, HNSCC, SCC, MCC \\
\hline & Poly ICLC & 1 & NCT02834052 & CoC \\
\hline \multirow[t]{3}{*}{ Toripalimab } & - & 1 & NCT02857166 & Neoplasms \\
\hline & - & 1 & NCT03713905 & Neoplasms \\
\hline & Anti-VEGFR (surufatinib) & 1 & NCT03879057 & NeT, LiC, GC \\
\hline GLS-010 & - & II & NCT03704246 & Neoplasms \\
\hline HX008 & - & 1 & NCT03468751 & Neoplasms \\
\hline HLX10 & - & 1 & NCT02715284 & NSCLC, EC, MSI-H \\
\hline AK105 & - & 1 & NCT03352531 & AST \\
\hline SG001 & - & 1 & NCT03852823 & AST \\
\hline CS1003 & - & 1 & NCT03809767 & Neoplasms \\
\hline SCT-I10A & - & 1 & NCT03821363 & Neoplasms \\
\hline Sym021 & Anti-LAG3 (Sym022) or anti-TIM3 (Sym023) & 1 & NCT03311412 & AST \\
\hline \multirow[t]{5}{*}{ Tislelizumab } & - & II & NCT03736889 & $\mathrm{MSI}-\mathrm{H}$ \\
\hline & Anti-TIM-3 (BGB-A425) & $1 / I 1$ & NCT03744468 & AST \\
\hline & Anti-TIGIT (BGB-A1217) & I & NCT04047862 & AST \\
\hline & Anti PD-L1 (BGB-A333) & 1/II & NCT03379259 & AST \\
\hline & PARP inhibitor (BGB-290) & 1 & NCT02660034 & AST \\
\hline & Anti-VEGF (axitinib) & II & NCT03595124 & RCC \\
\hline & Relatlimab + ipilimumab & II & NCT04080804 & HNSCC \\
\hline & $\begin{array}{l}\text { Relatlimab or ipilimumab + IDO1 inhibitor } \\
\text { (BMS-986205) }\end{array}$ & | $/ / 1$ & NCT03459222 & LAST \\
\hline & $\begin{array}{l}\text { Pembrolizumab + a protein kinase } \mathrm{C} \text { inhibitor } \\
\text { (trigriluzole) }\end{array}$ & $\|$ & NCT03229278 & AST, RCC, HNSCC, NSCLC, BIC, M \\
\hline & $\begin{array}{l}\text { Ipilimumab or RGX-104 or docetaxel or } \\
\text { pembrolizumab or carboplatin or demetrexed }\end{array}$ & 1 & NCT02922764 & AST, NSCLC \\
\hline & $\begin{array}{l}\text { Adenoviral product (Ad-p53) + pembrolizumab or } \\
\text { capecitabine }\end{array}$ & 1/II & NCT02842125 & AST, HNSCC \\
\hline & Genetically modified HSV for tumor lysis (RP1) & 1/II & NCT03767348 & $\mathrm{M}, \mathrm{BIC}, \mathrm{MRD}, \mathrm{MSI}-\mathrm{H}$ \\
\hline \multirow[t]{2}{*}{ Avelumab } & DC1c (BDCA-1) + myeloid DC + ipilimumab & 1 & NCT03707808 & Neoplasms \\
\hline & Anti-EGFR (cetuximab) + irinotecan & II & NCT03608046 & $\mathrm{CoC}$ \\
\hline ABBV-181 & $\begin{array}{l}\text { Anti-delta-like } 3 \text { protein (rovalpituzumab) or } \\
\text { venetoclax }\end{array}$ & 1 & NCT03000257 & $\begin{array}{l}\text { NSCLC, TNIBC, OC, HC, GC, SCLC, Me, Cho, } \\
\text { MCC, HNSCC }\end{array}$ \\
\hline Sintilimab & $\mathrm{IBI} \mid 310$ & 1 & NCT03545971 & AST \\
\hline Spartalizumab, PDR001 & Adenosine A2A receptor antagonist (NIR178) & II & NCT03207867 & $\begin{array}{l}\text { NSCLC, RCC, PC, UC, HNSCC, MSCC, } \\
\text { TNIBC, M }\end{array}$ \\
\hline SHR-1210 & Parp inhibitor (SHR3162) & 1 & NCT03182673 & AST \\
\hline
\end{tabular}


TABLE 1 | Continued

\begin{tabular}{|c|c|c|c|c|}
\hline Antibodies & In combination with & Phase & $\begin{array}{l}\text { ClinicalTrial.gov } \\
\text { identifier }\end{array}$ & Tumor \\
\hline JNJ 63723283 & Anti-FGFR1-4 & 1 & NCT03547037 & Neoplasms \\
\hline AGEN2034 & AGEN1884 & II & NCT03894215 & $\mathrm{CeC}$ \\
\hline \multicolumn{5}{|l|}{ mAbs targeting PD-L1 } \\
\hline HLX20 & - & 1 & NCT03588650 & Neoplasms \\
\hline KN035 & - & 1 & NCT03248843 & LAMST \\
\hline Atezolizumab & - & 1 & NCT02862275 & Neoplasms \\
\hline CS1001 & - & $\mathrm{la} / \mathrm{lb}$ & NCT03312842 & AST \\
\hline MSB2311 & - & 1 & NCT03463473 & AST \\
\hline SHR-1316 & - & 1 & NCT03133247 & AST \\
\hline CK-301 & - & 1 & NCT03212404 & NSCLC, CC, HNSCC, M, RCC, UC, CoC, EC \\
\hline & Tremelimumab + azacitidine & $\mathrm{Ib} / \mathrm{ll}$ & NCT03019003 & HNSCC \\
\hline & Tremelimumab + radiation therapy & II & NCT03601455 & $\mathrm{BIC}$ \\
\hline & Tremelimumab + stereotactic body radiotherapy & $\mathrm{Ib}$ & NCT03275597 & NSCLC \\
\hline & Tremelimumab + metronomic vinorelbine & 1/II & NCT03518606 & BC, HNSCC, CeC, PrC \\
\hline Avelumab & $\begin{array}{l}\text { Anti-TNFRSF9 (utomilumab) + anti-OX40 } \\
(\text { PF-04518600) + radiation therapy }\end{array}$ & 1/II & NCT03217747 & AST, PrC \\
\hline \multicolumn{5}{|l|}{ mAbs targeting CTLA-4 } \\
\hline $\begin{array}{l}\text { Fc-engineered lgG1 } \\
\text { (AGEN1181) }\end{array}$ & - & 1 & NCT03860272 & AST \\
\hline Tremelimumab & PARP inhibitor (olaparib) & 1/II & NCT02571725 & $\mathrm{OC}$ \\
\hline REGN4659 & Cemiplimab & 1 & NCT03580694 & NSCLC \\
\hline INCAGNO02390 & - & I & NCT03652077 & $\begin{array}{l}\text { CeC, GC, GC, EsC, HC, M, MCC, Me, NSCLC, } \\
\text { Oc, HNSCC, RCC, MRD, UC }\end{array}$ \\
\hline TSR-022 & TSR-042 or anti-LAG3 (TRS-033) & 1 & NCT02817633 & LAMST, CC, NSCLC \\
\hline LY3321367 & LY3300054 & 1 & NCT03099109 & AST \\
\hline BGB-A425 & Tislelizumab & $1 / 11$ & NCT03744468 & LAST \\
\hline \multicolumn{5}{|l|}{ BISPECIFIC mAbs } \\
\hline $\begin{array}{l}\text { Anti-PD-1/anti-LAG3 } \\
\text { (MDG013) }\end{array}$ & Anti-HER2 (margetuximab) & 1 & NCT03219268 & Neoplasms \\
\hline $\begin{array}{l}\text { Anti-PD-1/anti-TIM3 } \\
\text { (RO7121661) }\end{array}$ & - & 1 & NCT03708328 & MeM, NSCLC, SCLC \\
\hline $\begin{array}{l}\text { Anti-PD-1/anti-CTLA-4 } \\
\text { (AK104) }\end{array}$ & Oxaliplatin + capecitabine & I/II & NCT03852251 & GC \\
\hline $\begin{array}{l}\text { Anti-PD-1/anti-CTLA-4 } \\
\text { (MGD019 DART) }\end{array}$ & - & 1 & NCT03761017 & AST \\
\hline $\begin{array}{l}\text { Anti-PD-L1/anti-TIM3 } \\
\text { (LY3415244) }\end{array}$ & - & 1 & NCT03752177 & AST \\
\hline $\begin{array}{l}\text { Anti-CTLA-4/anti-OX40 } \\
\text { (ATOR-1015) }\end{array}$ & - & 1 & NCT03782467 & AST \\
\hline
\end{tabular}


TABLE 1 | Continued

\begin{tabular}{|c|c|c|c|c|}
\hline Antibodies & In combination with & Phase & $\begin{array}{l}\text { ClinicalTrial.gov } \\
\text { identifier }\end{array}$ & Tumor \\
\hline $\begin{array}{l}\text { Anti-CTLA-4/anti-LAG3 } \\
\left(\mathrm{XmAb}^{\circledR} 22841\right)\end{array}$ & Pembrolizumab & 1 & NCT03849469 & AST \\
\hline Anti-HER2 (MBS301) & - & 1 & NCT03842085 & $\mathrm{BC}, \mathrm{SC}$ \\
\hline $\begin{array}{l}\text { Anti-GD2/anti-CD3 } \\
\text { (hu3F8-BsAb) }\end{array}$ & - & $1 / I 1$ & NCT03860207 & $\mathrm{NB}, \mathrm{OS}$ \\
\hline \multicolumn{5}{|l|}{ Fusion protein } \\
\hline $\begin{array}{l}\text { Anti-PD-L1/TGF } \beta R \| I \\
\text { (M7824) }\end{array}$ & - & $I / I I$ & NCT03436563 & MSI-H RC, CoC \\
\hline
\end{tabular}

"Immune checkpoint inhibitors reported in the column indicating the "combination" treatment: ipilimumab, pembrolizumab, AGEN1884, IBI310, tremelimumab, BMS-986218: anti-CTLA-4; nivolumab, pembrolizumab, TRS-042, tislelizumab, cemiplimab: anti-PD-1; atezolizumab, avelumab, durvalumab, LY3300054: anti-PD-L1.

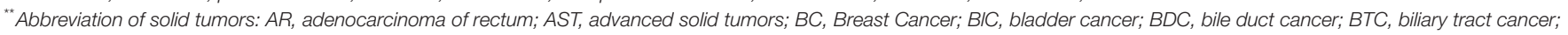
CeC, Cervical Cancer; Cho, cholangiocarcinoma; CoC, Colorectal Cancer; CoS, chondrosarcoma; EC, endometrial cancer; EsC, esophageal cancer; ES, Ewing's sarcoma; ESCC, esophageal squamous cell carcinoma; FTC, fallopian tube cancer; GC, Gastric Cancer; GyC, gynecological cancers; GB, glioblastoma, HC, Hepatocellular Carcinoma; HNSCC,

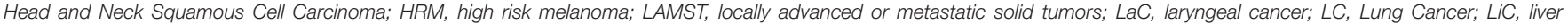

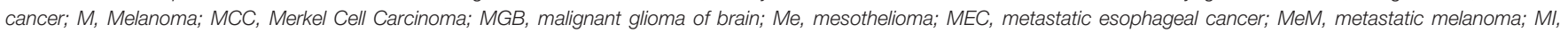

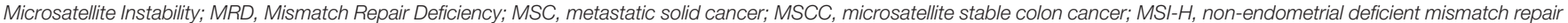

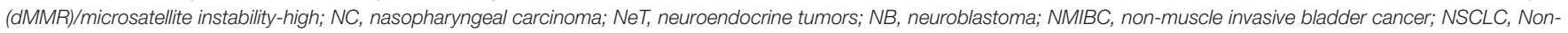

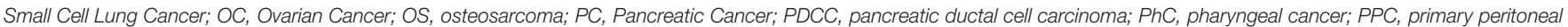
cancer; PrC, prostate carcinoma; RCC, Renal Cell Carcinoma; RS, rhabdomyosarcoma; SC, stomach cancer; SCC, squamous cell carcinoma; SCLC, Small Cell Lung Cancer; STS, soft tissue sarcoma; TC, Thyroid Cancer; TNIBC, triple-negative invasive breast carcinoma; ToC, tongue cancer; UC, Urothelial Carcinoma; UrC, urological cancer. Abbreviation of cells: DCs, dendritic cells; CIK, Cytokine-induced killer cells.

NK cells in vitro by reducing their apoptosis (170). In a xenograft model, anti-PD1 suppressed the tumor growth of digestive cancers in an NK cell-dependent manner, suggesting a crucial role of PD1 in NK cell function (170). Moreover, anti-CTLA-4 combined with IL-15/IL-15R $\alpha$ enhances the NK cell tumor infiltration, improving the tumor growth control in xenograft murine models of solid tumors. Melanoma patients treated with anti-CTLA-4 (ipilimumab) had higher intratumoral CD56 expression (171). Consistently, several phase I and II clinical trials are ongoing to test the efficacy of different anti-PD1, anti PD-L1, and anti-CTLA-4 mAbs, alone or in combination with other Abs, in multiple forms of advanced and metastatic solid tumors (Table 1). The competition of TIGIT and CD96 binding to DNAM-1 ligands PVR and Nectin-2 renders tumor-infiltrating NK cells exhausted (172-174). TIGITtargeting therapy represents a promising cure for solid tumor $(172,173,175)$. In preclinical studies, the murine model antiTIGIT is able to improve the antitumor effect of anti-HER2 $\mathrm{mAb}$ (176) alone, and in combination with PD1/PD-L1 inhibitors (176). Preclinical studies showed that CD96 blocking combined with anti-PD1 or anti-CTLA-4 enhances NK cell infiltration and IFN- $\gamma$ production, thus reducing tumor lung metastases (177). The blockade of TIM-3 was also found to enhance NK cell function against melanoma cells (178). The therapeutic efficacy of the combined use of different immune checkpoint inhibitors, such as anti-TIM-3 and anti-TIGIT, is currently tested in ongoing phase I and II clinical trials in solid tumor patients (Table 1).

Different bispecific mAbs for immune checkpoint inhibitors and for GD2-CD3 are in phase I and II clinical trials, respectively (Table 1). In addition, various bispecific NK cell engaging antibodies, such as ErbB2-CD16, EpCAM-CD16, and HER2-CD16, were promising for solid tumors in preclinical studies (179-181). Interestingly, the combined use of antibodies with cytokines, such as anti-GD2/GM-CSF/IL-2 (182, 183), as well as the adoption of the novel fusion proteins by linking antibodies to cytokines, such as anti-GD2 to IL15 superagonist (184), or the TNF-targeting human IgG1 NHS76 to IL-12 (185), reported great therapeutic results. Currently, the fusion protein anti-PD-L1/TGF $\beta$ RII is in phase I/II clinical trial (Table 1). The use of a novel monomeric carcinoembryonic-antigen (CEA)-targeted immunocytokine, or cergutuzumab amunaleukin (CEA-IL2v, RG7813), has shown success in preclinical models of colon cancer, resulting in a large expansion of $\mathrm{NK}$ cells and activation of $\mathrm{T}$ cells (186).

\section{Adoptive Transfer of NK and CAR-NK Cells}

Recently, great interest in the treatment of solid tumors is focused on the adoptive transfer of ex vivo expanded and activated NK cells that, for their peculiar innate features, relatively short lifespan, low risk of overexpression in infused patients, higher safety compared to infused $\mathrm{T}$ cells, and low costs, could represent an optimal therapeutic strategy (187, 188). Activated and expanded NK cells can be obtained by different sources, including NK cell lines, primary NK cells, umbilical cord blood (UCB)- and induced pluripotent stem cell (iPSC)-derived NK cells (189) (Table 1). Of note, NK cells are tolerant to health cells and sensible to tumor cells, mostly in alloreactive conditions (190). Thus, haploidentical allogenic NK cells represent an optimal cellular immunotherapy product, mainly for immunocompromising diseases, including solid tumors, whose patients can scantly count on their own cells and often need donor NK cells (191-193). Interestingly, there are several clinical trials in phase I and II in progress to treat solid tumors based on NK cell adoptive transfer combined with ALT803, mAbs, anti-cancer drugs, irreversible electroporation, and 
TABLE 2 | Some selected and most recent clinical trials (since January 1st 2016) on NK cell-based immunotherapies, in different forms of solid tumors, by using adoptive transfer of NK and CAR-NK cells.

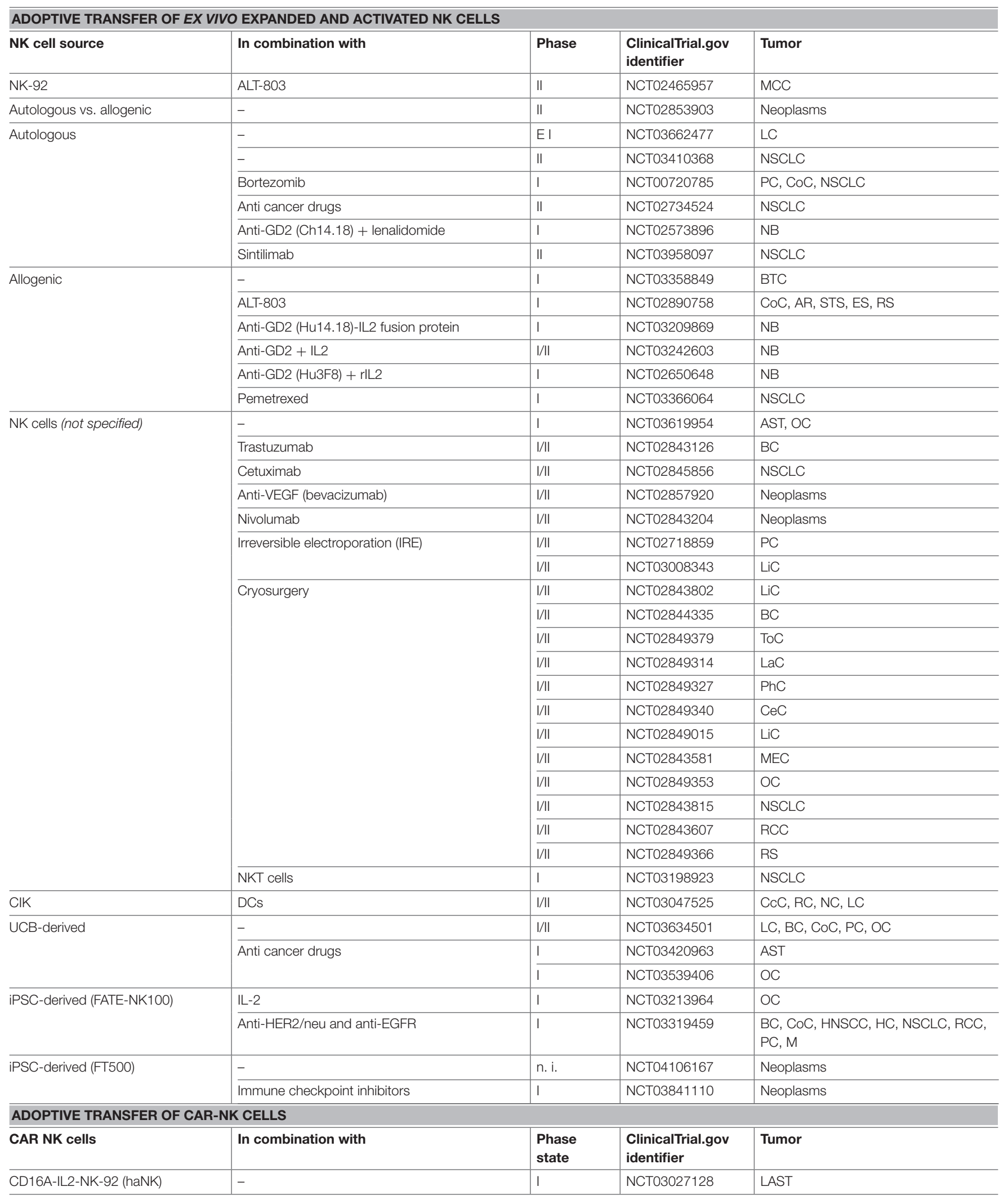


TABLE 2 | Continued

\begin{tabular}{|c|c|c|c|c|}
\hline CAR NK cells & In combination with & $\begin{array}{l}\text { Phase } \\
\text { state }\end{array}$ & $\begin{array}{l}\text { ClinicalTrial.gov } \\
\text { identifier }\end{array}$ & Tumor \\
\hline & IL-15 superagonist (N-803) and avelumab & $\|$ & NCT03853317 & MCC \\
\hline & $\begin{array}{l}\text { Anti-cancer drugs, vaccines and immune } \\
\text { checkpoint inhibitors }\end{array}$ & $1 / I I$ & NCT03387111 & SCC, neoplasms \\
\hline ROBO1-NK cells & - & I/II & NCT03940820 & Neoplasms \\
\hline $\begin{array}{l}\text { BiCAR-NK cells (ROBO1 CAR-NK } \\
\text { cells) }\end{array}$ & - & $1 / 11$ & NCT03941457 & PC \\
\hline ErbB2/HER2-NK (NK-92/5.28z) & Intracranial application & I & NCT03383978 & GB \\
\hline NKG2D-NK & $\mathrm{IL}-2$ & I & NCT03415100 & Neoplasms, OC \\
\hline MUC1-NK & - & $1 / I I$ & NCT02839954 & $\begin{array}{l}\text { HC, NSCLC, PC, TNIBC, MGB, CoC, } \\
\text { GC }\end{array}$ \\
\hline
\end{tabular}

Abbreviation of solid tumors and immune checkpoint inhibitors reported in the column indicating the "combination" treatment: see Table 1 legend.

Abbreviation of cells: DCs, dendritic cells; CIK, Cytokine-induced killer cells; NKT, natural killer-T cells; iPSC, induced pluripotent stem cells; UCB, umbilical cord blood. Other abbreviations:

El, early I phase; n. i., non-interventional, observational study.

cryosurgery (Table 2). This approach could overcome the effects of tumor immune evasion $(194,195)$ since mature and activated NK cells provided by current protocol of iPSC-derived NK cell expansion are able to infiltrate and kill solid tumors. This was firstly evaluated in a murine xenograft model of ovarian cancer (196), and more recently in subjects with advanced solid tumors as monotherapy and in combination with mAb (NCT03319459) or antitumor drugs (NCT03213964) (Table 2). Of interest, among most efficient immune-modulatory drugs able to induce ligands for NK-ARs on cancer cells (197), lenalidomide is used in a clinical setting in combination with expanded and activated NK cells in some hematopoietic malignancies and neuroblastoma patients (NCT02573896).

In order to potentiate both the specificity and activity of NK cells against solid tumors, genetically modified NK cells have been produced and clinically adopted with promising results. NK cells obtained by different sources have been engineered for CARs able to recognize specific tumor antigens or ligands for activating receptors (198-201). To avoid the need of exogenous IL-2 in culture, high-affinity NK (haNK) cells were obtained by engineering the NK-92 cell line for the expression of CD16A and IL-2 (202) and used in patients with solid tumors (NCT03027128). Several CAR-engineered NK cells recognizing EGFR for breast cancer brain metastases (203), both ErbB2/HER2 (204, 205) (NCT03383978) upon intracranial injection, and EGFRvIII (206) for glioblastoma, GD2 for neuroblastoma (207), EpCAM for breast carcinoma (208), NKG2D for ovarian cancer (201), and both MUC1 and ROBO1 for advanced refractory solid tumors, have been produced for preclinical studies and phase I and II clinical trials (Table 2). Finally, of emerging interest are the extracellular vesicles (EVs) secreted by large-scale in vitro expanded NK cells, that, containing lytic protein, showed antitumor efficacy not only in malignant hematopoietic cell lines but also in neuroblastoma and breast carcinoma cell lines, and in a xenograft murine model of glioblastoma $(209,210)$.

\section{PERSPECTIVES}

NK cells play a crucial role in triggering antitumor immune response. Although high levels of tumor infiltrating NK cells are associated with a better prognosis in certain human solid tumors, the immunosuppressive TME weakens their function in favor of neoplastic progression. Understanding the mechanisms adopted by the TME to hinder the NK cell function and how they can be neutralized is of fundamental importance to develop effective anti-cancer therapeutic protocols. In this regard, the use of NK cell-based immunotherapy, by the combined use of cytokines, mAbs, immune checkpoint inhibitors, and the adoptive transfer of NK cells and CAR-NK cells, appears to be promising in the treatment of solid tumors.

A significant number of cancer immunotherapies that involved engineering $\mathrm{NK}$ cells before adoptive transfer into patients have been developed. There is the possibility of engineering NK cells to make them resistant to the metabolically restrictive TME as well as to immunosuppressive molecules generated by the tumor and TME.

Overall, it is now clear that TME is crucial for the normal function of $\mathrm{NK}$ cells and that future investigations and preclinical studies in this area are likely needed to fully discern the biology of NK cells and reveal new and exciting anti-cancer therapeutic opportunities.

\section{AUTHOR CONTRIBUTIONS}

All the authors edited the manuscript and approved the final version for publication.

\section{FUNDING}

This work was supported by grants from the Associazione Italiana Ricerca Cancro (AIRC) \#IG18495 and the Italian Ministry of Health \#PE-2011-02351866 to DF and a fellowship from the Fondazione Umberto Veronesi to VL. 


\section{REFERENCES}

1. Barrow AD, Martin CJ, Colonna M. The natural cytotoxicity receptors in health and disease. Front Immunol. (2019) 10:909. doi: 10.3389/fimmu.2019.00909

2. Arase H, Mocarski ES, Campbell AE, Hill AB, Lanier LL. Direct recognition of cytomegalovirus by activating and inhibitory NK cell receptors. Science. (2002) 296:1323-6. doi: 10.1126/science.1070884

3. Raulet DH, Gasser S, Gowen BG, Deng W, Jung H. Regulation of ligands for the NKG2D activating receptor. Annu Rev Immunol. (2013) 31:413-41. doi: 10.1146/annurev-immunol-032712-095951

4. Barrow AD, Edeling MA, Trifonov V, Luo J, Goyal P, Bohl B, et al. Natural killer cells control tumor growth by sensing a growth factor. Cell. (2018) 172:534-48 e519. doi: 10.1016/j.cell.2017.11.037

5. Susek KH, Karvouni M, Alici E, Lundqvist A. The role of CXC chemokine receptors 1-4 on immune cells in the tumor microenvironment. Front Immunol. (2018) 9:2159. doi: 10.3389/fimmu.2018.02159

6. Spiegel A, Brooks MW, Houshyar S, Reinhardt F, Ardolino M, Fessler E, et al. Neutrophils suppress intraluminal NK cell-mediated tumor cell clearance and enhance extravasation of disseminated carcinoma cells. Cancer Discov. (2016) 6:630-49. doi: 10.1158/2159-8290.CD-15-1157

7. Diefenbach A, Jensen ER, Jamieson AM, Raulet DH. Rael and H60 ligands of the NKG2D receptor stimulate tumour immunity. Nature. (2001) 413:16571. doi: 10.1038/35093109

8. Malladi S, Macalinao DG, Jin X, He L, Basnet H, Zou Y, et al. Metastatic latency and immune evasion through autocrine inhibition of WNT. Cell. (2016) 165:45-60. doi: 10.1016/j.cell.2016.02.025

9. Glasner A, Ghadially H, Gur C, Stanietsky N, Tsukerman P, Enk J, et al. Recognition and prevention of tumor metastasis by the NK receptor NKp46/NCR1. J Immunol. (2012) 188:2509-15. doi: 10.4049/jimmunol.1102461

10. Sathe P, Delconte RB, Souza-Fonseca-Guimaraes F, Seillet C, Chopin $\mathrm{M}$, Vandenberg CJ, et al. Innate immunodeficiency following genetic ablation of Mcl1 in natural killer cells. Nat Commun. (2014) 5:4539. doi: 10.1038/ncomms5539

11. Merzoug LB, Marie S, Satoh-Takayama N, Lesjean S, Albanesi M, Luche H, et al. Conditional ablation of NKp46+ cells using a novel Ncrl(greenCre) mouse strain: NK cells are essential for protection against pulmonary B16 metastases. Eur J Immunol. (2014) 44:3380-91. doi: 10.1002/eji.201444643

12. Guillerey C, Chow MT, Miles K, Olver S, Sceneay J, Takeda K, et al. Toll-like receptor 3 regulates NK cell responses to cytokines and controls experimental metastasis. Oncoimmunology. (2015) 4:e1027468. doi: 10.1080/2162402X.2015.1027468

13. Iguchi-Manaka A, Kai H, Yamashita Y, Shibata K, Tahara-Hanaoka S, Honda $\mathrm{S}$, et al. Accelerated tumor growth in mice deficient in DNAM-1 receptor. $J$ Exp Med. (2008) 205:2959-64. doi: 10.1084/jem.20081611

14. Malaise M, Rovira J, Renner P, Eggenhofer E, Sabet-Baktach M, Lantow M, et al. KLRG1+ NK cells protect T-bet-deficient mice from pulmonary metastatic colorectal carcinoma. J Immunol. (2014) 192:1954-61. doi: 10.4049/jimmunol.1300876

15. Putz EM, Mayfosh AJ, Kos K, Barkauskas DS, Nakamura K, Town L, et al. NK cell heparanase controls tumor invasion and immune surveillance. J Clin Invest. (2017) 127:2777-88. doi: 10.1172/JCI92958

16. Luna JI, Grossenbacher SK, Murphy WJ, Canter RJ. Targeting cancer stem cells with natural killer cell immunotherapy. Expert Opin Biol Ther. (2017) 17:313-24. doi: 10.1080/14712598.2017.1271874

17. Kaur K, Nanut MP, Ko MW, Safaie T, Kos J, Jewett A. Natural killer cells target and differentiate cancer stem-like cells/undifferentiated tumors: strategies to optimize their growth and expansion for effective cancer immunotherapy. Curr Opin Immunol. (2018) 51:170-80. doi: 10.1016/j.coi.2018.03.022

18. Lau EY, Ho NP, Lee TK. Cancer stem cells and their microenvironment: biology and therapeutic implications. Stem Cells Int. (2017) 2017:3714190. doi: 10.1155/2017/3714190

19. Tallerico R, Todaro M, Di Franco S, Maccalli C, Garofalo C, Sottile R, et al. Human NK cells selective targeting of colon cancer-initiating cells: a role for natural cytotoxicity receptors and MHC class I molecules. J Immunol. (2013) 190:2381-90. doi: 10.4049/jimmunol.1201542
20. Ames E, Canter RJ, Grossenbacher SK, Mac S, Chen M, Smith RC, et al. NK cells preferentially target tumor cells with a cancer stem cell phenotype. $J$ Immunol. (2015) 195:4010-9. doi: 10.4049/jimmunol.1500447

21. Castriconi R, Daga A, Dondero A, Zona G, Poliani PL, Melotti A, et al. NK cells recognize and kill human glioblastoma cells with stem cell-like properties. J Immunol. (2009) 182:3530-9. doi: 10.4049/jimmunol.0802845

22. Pietra G, Manzini C, Vitale M, Balsamo M, Ognio E, Boitano M, et al. Natural killer cells kill human melanoma cells with characteristics of cancer stem cells. Int Immunol. (2009) 21:793-801. doi: 10.1093/intimm/dxp047

23. Yin T, Wang G, He S, Liu Q, Sun J, Wang Y. Human cancer cells with stem cell-like phenotype exhibit enhanced sensitivity to the cytotoxicity of IL-2 and IL-15 activated natural killer cells. Cell Immunol. (2016) 300:41-5. doi: 10.1016/j.cellimm.2015.11.009

24. Canter RJ, Ames E, Mac S, Grossenbacher SK, Chen M, Li CS, et al. Anti-proliferative but not anti-angiogenic tyrosine kinase inhibitors enrich for cancer stem cells in soft tissue sarcoma. BMC Cancer. (2014) 14:756. doi: 10.1186/1471-2407-14-756

25. Ames E, Canter RJ, Grossenbacher SK, Mac S, Smith RC, Monjazeb $\mathrm{AM}$, et al. Enhanced targeting of stem-like solid tumor cells with radiation and natural killer cells. Oncoimmunology. (2015) 4:e1036212. doi: 10.1080/2162402X.2015.1036212

26. Kozlowska AK, Topchyan P, Kaur K, Tseng HC, Teruel A, Hiraga T, et al. Differentiation by NK cells is a prerequisite for effective targeting of cancer stem cells/poorly differentiated tumors by chemopreventive and chemotherapeutic drugs. J Cancer. (2017) 8:537-54. doi: 10.7150/jca.15989

27. Kozlowska AK, Kaur K, Topchyan P, Jewett A. Adoptive transfer of osteoclast-expanded natural killer cells for immunotherapy targeting cancer stem-like cells in humanized mice. Cancer Immunol Immunother. (2016) 65:835-45. doi: 10.1007/s00262-016-1822-9

28. Tseng HC, Bui V, Man YG, Cacalano N, Jewett A. Induction of split anergy conditions natural killer cells to promote differentiation of stem cells through cell-cell contact and secreted factors. Front Immunol. (2014) 5:269. doi: 10.3389/fimmu.2014.00269

29. Stevens A, Kloter I, Roggendorf W. Inflammatory infiltrates and natural killer cell presence in human brain tumors. Cancer. (1988) 61:738-43. doi: 10.1002/1097-0142(19880215)61:4<738::AID-CNCR2820610417>3.0. CO;2-E

30. Tartter PI, Steinberg B, Barron DM, Martinelli G. The prognostic significance of natural killer cytotoxicity in patients with colorectal cancer. Arch Surg. (1987) 122:1264-8. doi: 10.1001/archsurg.1987.01400230050009

31. Schantz SP, Savage HE, Racz T, Taylor DL, Sacks PG. Natural killer cells and metastases from pharyngeal carcinoma. Am J Surg. (1989) 158:361-6. doi: 10.1016/0002-9610(89)90134-7

32. Brittenden J, Heys SD, Ross J, Eremin O. Natural killer cells and cancer. Cancer. (1996) 77:1226-43. doi: $\quad$ 10.1002/(SICI)1097-0142(19960401)77:7<1226::AID-CNCR2>3.0. $\mathrm{CO} ; 2-\mathrm{G}$

33. Denkert C, von Minckwitz G, Darb-Esfahani S, Lederer B, Heppner $\mathrm{BI}$, Weber KE, et al. Tumour-infiltrating lymphocytes and prognosis in different subtypes of breast cancer: a pooled analysis of 3771 patients treated with neoadjuvant therapy. Lancet Oncol. (2018) 19:40-50. doi: 10.1016/S1470-2045(17)30904-X

34. Arnould L, Gelly M, Penault-Llorca F, Benoit L, Bonnetain F, Migeon C, et al. Trastuzumab-based treatment of HER2-positive breast cancer: an antibodydependent cellular cytotoxicity mechanism? Br J Cancer. (2006) 94:259-67. doi: 10.1038/sj.bjc.6602930

35. Muntasell A, Rojo F, Servitja S, Rubio-Perez C, Cabo M, Tamborero D, et al. NK cell infiltrates and HLA class I expression in primary HER2 $(+)$ breast cancer predict and uncouple pathological response and disease-free survival. Clin Cancer Res. (2019) 25:1535-45. doi: 10.1158/1078-0432.CCR-18-2365

36. Muntasell A, Servitja S, Cabo M, Bermejo B, Perez-Buira S, Rojo F, et al. High numbers of circulating CD57(+) NK cells associate with resistance to HER2specific therapeutic antibodies in HER2 $(+)$ primary breast cancer. Cancer Immunol Res. (2019) 7:1280-92. doi: 10.1158/2326-6066.CIR-18-0896

37. Ali TH, Pisanti S, Ciaglia E, Mortarini R, Anichini A, Garofalo C, et al. Enrichment of CD56(dim)KIR + CD57 + highly cytotoxic NK cells in tumour-infiltrated lymph nodes of melanoma patients. Nat Commun. (2014) 5:5639. doi: $10.1038 /$ ncomms6639 
38. Messaoudene M, Fregni G, Fourmentraux-Neves E, Chanal J, Maubec E, Mazouz-Dorval S, et al. Mature cytotoxic CD56(bright)/CD16(+) natural killer cells can infiltrate lymph nodes adjacent to metastatic melanoma. Cancer Res. (2014) 74:81-92. doi: 10.1158/0008-5472.CAN-13-1303

39. Cursons J, Souza-Fonseca-Guimaraes F, Foroutan M, Anderson A, Hollande F, Hediyeh-Zadeh S, et al. A gene signature predicting natural killer cell infiltration and improved survival in melanoma patients. Cancer Immunol Res. (2019) 7:1162-74. doi: 10.1158/2326-6066.CIR-18-0500

40. Barry KC, Hsu J, Broz ML, Cueto FJ, Binnewies M, Combes AJ, et al. A natural killer-dendritic cell axis defines checkpoint therapyresponsive tumor microenvironments. Nat Med. (2018) 24:1178-91. doi: 10.1038/s41591-018-0085-8

41. Pernot S, Terme M, Radosevic-Robin N, Castan F, Badoual C, Marcheteau $\mathrm{E}$, et al. Infiltrating and peripheral immune cell analysis in advanced gastric cancer according to the Lauren classification and its prognostic significance. Gastric Cancer. (2019). doi: 10.1007/s10120-019-00983-3

42. Menard C, Blay JY, Borg C, Michiels S, Ghiringhelli F, Robert C, et al. Natural killer cell IFN-gamma levels predict long-term survival with imatinib mesylate therapy in gastrointestinal stromal tumor-bearing patients. Cancer Res. (2009) 69:3563-9. doi: 10.1158/0008-5472.CAN-08-3807

43. Delahaye NF, Rusakiewicz S, Martins I, Menard C, Roux S, Lyonnet L, et al. Alternatively spliced NKp30 isoforms affect the prognosis of gastrointestinal stromal tumors. Nat Med. (2011) 17:700-7. doi: 10.1038/nm.2366

44. Semeraro M, Rusakiewicz S, Minard-Colin V, Delahaye NF, Enot D, Vely F, et al. Clinical impact of the NKp30/B7-H6 axis in highrisk neuroblastoma patients. Sci Transl Med. (2015) 7:283ra255. doi: 10.1126/scitranslmed.aaa2327

45. Habif G, Crinier A, Andre P, Vivier E, Narni-Mancinelli E. Targeting natural killer cells in solid tumors. Cell Mol Immunol. (2019) 16:415-22. doi: 10.1038/s41423-019-0224-2

46. Pasero C, Gravis G, Guerin M, Granjeaud S, Thomassin-Piana J, Rocchi $\mathrm{P}$, et al. Inherent and tumor-driven immune tolerance in the prostate microenvironment impairs natural killer cell antitumor activity. Cancer Res. (2016) 76:2153-65. doi: 10.1158/0008-5472.CAN-15-1965

47. Eckl J, Buchner A, Prinz PU, Riesenberg R, Siegert SI, Kammerer R, et al. Transcript signature predicts tissue NK cell content and defines renal cell carcinoma subgroups independent of TNM staging. J Mol Med. (2012) 90:55-66. doi: 10.1007/s00109-011-0806-7

48. Schleypen JS, Baur N, Kammerer R, Nelson PJ, Rohrmann K, Grone EF, et al. Cytotoxic markers and frequency predict functional capacity of natural killer cells infiltrating renal cell carcinoma. Clin Cancer Res. (2006) $12(3 \mathrm{Pt}$ 1):718-25. doi: 10.1158/1078-0432.CCR-05-0857

49. Liljefors M, Nilsson B, Hjelm Skog AL, Ragnhammar P, Mellstedt H, Frodin JE. Natural killer (NK) cell function is a strong prognostic factor in colorectal carcinoma patients treated with the monoclonal antibody 17-1A. Int J Cancer. (2003) 105:717-23. doi: 10.1002/ijc.11139

50. Halama N, Braun M, Kahlert C, Spille A, Quack C, Rahbari N, et al. Natural killer cells are scarce in colorectal carcinoma tissue despite high levels of chemokines and cytokines. Clin Cancer Res. (2011) 17:678-89. doi: 10.1158/1078-0432.CCR-10-2173

51. Villegas FR, Coca S, Villarrubia VG, Jimenez R, Chillon MJ, Jareno J, et al. Prognostic significance of tumor infiltrating natural killer cells subset CD57 in patients with squamous cell lung cancer. Lung Cancer. (2002) 35:23-8. doi: 10.1016/S0169-5002(01)00292-6

52. Charrier M, Mezquita L, Lueza B, Dupraz L, Planchard D, Remon J, et al. Circulating innate immune markers and outcomes in treatmentnaive advanced non-small cell lung cancer patients. Eur J Cancer. (2019) 108:88-96. doi: 10.1016/j.ejca.2018.12.017

53. Carrega P, Morandi B, Costa R, Frumento G, Forte G, Altavilla G, et al. Natural killer cells infiltrating human nonsmall-cell lung cancer are enriched in CD56 bright CD16(-) cells and display an impaired capability to kill tumor cells. Cancer. (2008) 112:863-75. doi: 10.1002/cncr.23239

54. Carrega P, Ferlazzo G. Natural killers are made not born: how to exploit NK cells in lung malignancies. Front Immunol. (2017) 8:277. doi: 10.3389/fimmu.2017.00277

55. Lavin Y, Kobayashi S, Leader A, Amir ED, Elefant N, Bigenwald C, et al. Innate immune landscape in early lung adenocarcinoma by paired single-cell analyses. Cell. (2017) 169:750-65 e717. doi: 10.1016/j.cell.2017.04.014
56. Cai L, Zhang Z, Zhou L, Wang H, Fu J, Zhang S, et al. Functional impairment in circulating and intrahepatic NK cells and relative mechanism in hepatocellular carcinoma patients. Clin Immunol. (2008) 129:428-37. doi: 10.1016/j.clim.2008.08.012

57. Wu Y, Kuang DM, Pan WD, Wan YL, Lao XM, Wang D, et al. Monocyte/macrophage-elicited natural killer cell dysfunction in hepatocellular carcinoma is mediated by CD48/2B4 interactions. Hepatology. (2013) 57:1107-16. doi: 10.1002/hep.26192

58. Sun H, Liu L, Huang Q, Liu H, Huang M, Wang J, et al. Accumulation of tumor-infiltrating CD49a(+) NK cells correlates with poor prognosis for human hepatocellular carcinoma. Cancer Immunol Res. (2019) 7:1535-46. doi: 10.1158/2326-6066.CIR-18-0757

59. Degos C, Heinemann M, Barrou J, Boucherit N, Lambaudie E, Savina A, et al. Endometrial tumor microenvironment alters human NK cell recruitment, and resident NK cell phenotype and function. Front Immunol. (2019) 10:877. doi: 10.3389/fimmu.2019.00877

60. Castriconi R, Carrega P, Dondero A, Bellora F, Casu B, Regis S, et al. Molecular mechanisms directing migration and retention of natural killer cells in human tissues. Front Immunol. (2018) 9:2324. doi: 10.3389/fimmu.2018.02324

61. Batlle E, Massague J. Transforming growth factor-beta signaling in immunity and cancer. Immunity. (2019) 50:924-40. doi: 10.1016/j.immuni.2019.03.024

62. Wahl SM, Wen J, Moutsopoulos NM. The kiss of death: interrupted by NKcell close encounters of another kind. Trends Immunol. (2006) 27:161-4. doi: 10.1016/j.it.2006.02.002

63. Ghiringhelli F, Menard C, Terme M, Flament C, Taieb J, Chaput N, et al. $\mathrm{CD} 4+\mathrm{CD} 25+$ regulatory $\mathrm{T}$ cells inhibit natural killer cell functions in a transforming growth factor-beta-dependent manner. J Exp Med. (2005) 202:1075-85. doi: 10.1084/jem.20051511

64. Trotta R, Dal Col J, Yu J, Ciarlariello D, Thomas B, Zhang X, et al. TGFbeta utilizes SMAD3 to inhibit CD16-mediated IFN-gamma production and antibody-dependent cellular cytotoxicity in human NK cells. J Immunol. (2008) 181:3784-92. doi: 10.4049/jimmunol.181.6.3784

65. Castriconi R, Cantoni C, Della Chiesa M, Vitale M, Marcenaro E, Conte $\mathrm{R}$, et al. Transforming growth factor beta 1 inhibits expression of NKp30 and NKG2D receptors: consequences for the NK-mediated killing of dendritic cells. Proc Natl Acad Sci USA. (2003) 100:4120-5. doi: 10.1073/pnas.0730640100

66. Friese MA, Wischhusen J, Wick W, Weiler M, Eisele G, Steinle A, et al. RNA interference targeting transforming growth factor-beta enhances NKG2Dmediated antiglioma immune response, inhibits glioma cell migration and invasiveness, and abrogates tumorigenicity in vivo. Cancer Res. (2004) 64:7596-603. doi: 10.1158/0008-5472.CAN-04-1627

67. Crane CA, Han SJ, Barry JJ, Ahn BJ, Lanier LL, Parsa AT. TGFbeta downregulates the activating receptor NKG2D on NK cells and CD8+ T cells in glioma patients. Neuro Oncol. (2010) 12:7-13. doi: 10.1093/neuonc/nop009

68. Lee JC, Lee KM, Kim DW, Heo DS. Elevated TGF-beta1 secretion and down-modulation of NKG2D underlies impaired NK cytotoxicity in cancer patients. J Immunol. (2004) 172:7335-40. doi: 10.4049/jimmunol.172.12.7335

69. Donatelli SS, Zhou JM, Gilvary DL, Eksioglu EA, Chen X, Cress WD, et al. TGF-beta-inducible microRNA-183 silences tumor-associated natural killer cells. Proc Natl Acad Sci USA. (2014) 111:4203-8. doi: 10.1073/pnas.1319269111

70. Li H, Han Y, Guo Q, Zhang M, Cao X. Cancer-expanded myeloid-derived suppressor cells induce anergy of NK cells through membrane-bound TGFbeta 1. J Immunol. (2009) 182:240-9. doi: 10.4049/jimmunol.182.1.240

71. Viel S, Marcais A, Guimaraes FS, Loftus R, Rabilloud J, Grau M, et al. TGF-beta inhibits the activation and functions of NK cells by repressing the mTOR pathway. Sci Signal. (2016) 9:ra19. doi: 10.1126/scisignal. aad 1884

72. Gao Y, Souza-Fonseca-Guimaraes F, Bald T, Ng SS, Young A, Ngiow SF, et al. Tumor immunoevasion by the conversion of effector NK cells into type 1 innate lymphoid cells. Nat Immunol. (2017) 18:1004-15. doi: $10.1038 /$ ni.3800

73. Cortez VS, Cervantes-Barragan L, Robinette ML, Bando JK, Wang Y, Geiger TL, et al. Transforming growth factor-beta signaling guides the 
differentiation of innate lymphoid cells in salivary glands. Immunity. (2016) 44:1127-39. doi: 10.1016/j.immuni.2016.03.007

74. Castriconi R, Dondero A, Bellora F, Moretta L, Castellano A, Locatelli F, et al. Neuroblastoma-derived TGF-betal modulates the chemokine receptor repertoire of human resting NK cells. J Immunol. (2013) 190:5321-8. doi: $10.4049 /$ jimmunol.1202693

75. Bellora F, Castriconi R, Dondero A, Pessino A, Nencioni A, Liggieri G, et al. TLR activation of tumor-associated macrophages from ovarian cancer patients triggers cytolytic activity of NK cells. Eur J Immunol. (2014) 44:1814-22. doi: 10.1002/eji.201344130

76. Dieu-Nosjean MC, Giraldo NA, Kaplon H, Germain C, Fridman WH, Sautes-Fridman C. Tertiary lymphoid structures, drivers of the antitumor responses in human cancers. Immunol Rev. (2016) 271:260-75. doi: 10.1111/imr.12405

77. Vanpouille-Box C, Diamond JM, Pilones KA, Zavadil J, Babb JS, Formenti SC, et al. TGFbeta is a master regulator of radiation therapy-induced antitumor immunity. Cancer Res. (2015) 75:2232-42. doi: 10.1158/0008-5472.CAN-14-3511

78. Rodriguez-Ruiz ME, Rodriguez I, Mayorga L, Labiano T, Barbes B, Etxeberria I, et al. TGFbeta blockade enhances radiotherapy abscopal efficacy effects in combination with anti-PD1 and anti-CD137 immunostimulatory monoclonal antibodies. Mol Cancer Therap. (2019) 18:621-31. doi: 10.1158/1535-7163.MCT-18-0558

79. Spender LC, Ferguson GJ, Hughes GD, Davies BR, Goldberg FW, Herrera B, et al. Preclinical evaluation of AZ12601011 and AZ12799734, inhibitors of transforming growth factor beta superfamily type 1 receptors. Mol Pharmacol. (2019) 95:222-34. doi: 10.1124/mol.118. 112946

80. Dodagatta-Marri E, Meyer DS, Reeves MQ, Paniagua R, To MD, Binnewies $\mathrm{M}$, et al. alpha-PD-1 therapy elevates Treg/Th balance and increases tumor cell pSmad 3 that are both targeted by alpha-TGFbeta antibody to promote durable rejection and immunity in squamous cell carcinomas. J Immunother Cancer. (2019) 7:62. doi: 10.1186/s40425-018-0493-9

81. Ravi R, Noonan KA, Pham V, Bedi R, Zhavoronkov A, Ozerov IV, et al. Bifunctional immune checkpoint-targeted antibodyligand traps that simultaneously disable TGFbeta enhance the efficacy of cancer immunotherapy. Nat Commun. (2018) 9:741. doi: 10.1038/s41467-017-02696-6

82. Takasaka N, Seed RI, Cormier A, Bondesson AJ, Lou J, Elattma A, et al. Integrin alphavbeta8-expressing tumor cells evade host immunity by regulating TGF-beta activation in immune cells. JCI Insight. (2018) 3:e122591. doi: 10.1172/jci.insight.122591

83. Gabriely G, da Cunha AP, Rezende RM, Kenyon B, Madi A, Vandeventer T, et al. Targeting latency-associated peptide promotes antitumor immunity. Sci Immunol. (2017) 2:eaaj1738. doi: 10.1126/sciimmunol.aaj1738

84. Holmgaard RB, Schaer DA, Li Y, Castaneda SP, Murphy MY, Xu X, et al. Targeting the TGF $\beta$ pathway with galunisertib, a TGFbetaRI small molecule inhibitor, promotes anti-tumor immunity leading to durable, complete responses, as monotherapy and in combination with checkpoint blockade. J Immunother Cancer. (2018) 6:47. doi: 10.1186/s40425-0180356-4

85. Mariathasan S, Turley SJ, Nickles D, Castiglioni A, Yuen K, Wang Y, et al. TGF $\beta$ attenuates tumour response to PD-L1 blockade by contributing to exclusion of T cells. Nature. (2018) 554:544-8. doi: 10.1038/nature25501

86. Tauriello DVF, Palomo-Ponce S, Stork D, Berenguer-Llergo A, BadiaRamentol J, Iglesias $\mathrm{M}$, et al. TGFbeta drives immune evasion in genetically reconstituted colon cancer metastasis. Nature. (2018) 554:538-43. doi: 10.1038/nature25492

87. Faivre SJ, Bouattour M, Dreyer C, Raymond E. Sunitinib in hepatocellular carcinoma: redefining appropriate dosing, schedule, and activity end points. J Clin Oncol. (2009) 27:e248-50. doi: 10.1200/JCO.2009.25.0670

88. Melisi D, Garcia-Carbonero R, Macarulla T, Pezet D, Deplanque G, Fuchs M, et al. Galunisertib plus gemcitabine vs. gemcitabine for first-line treatment of patients with unresectable pancreatic cancer. Br J Cancer. (2018) 119:120814. doi: 10.1038/s41416-018-0246-Z

89. Formenti SC, Lee P, Adams S, Goldberg JD, Li X, Xie MW, et al. Focal irradiation and systemic TGFbeta blockade in metastatic breast cancer. Clin Cancer Res. (2018) 24:2493-504. doi: 10.1158/1078-0432.CCR-17-3322
90. Kopp HG, Placke T, Salih HR. Platelet-derived transforming growth factor-beta down-regulates NKG2D thereby inhibiting natural killer cell antitumor reactivity. Cancer Res. (2009) 69:7775-83. doi: 10.1158/0008-5472.CAN-09-2123

91. O’Brien KL, Finlay DK. Immunometabolism and natural killer cell responses. Nat Rev Immunol. (2019) 19:282-90. doi: 10.1038/s41577-019-0139-2

92. Cong J, Wang X, Zheng X, Wang D, Fu B, Sun R, et al. Dysfunction of natural killer cells by FBP1-induced inhibition of glycolysis during lung cancer progression. Cell Metab. (2018) 28:243-55 e245. doi: 10.1016/j.cmet.2018.06.021

93. Caras I, Grigorescu A, Stavaru C, Radu DL, Mogos I, Szegli G, et al. Evidence for immune defects in breast and lung cancer patients. Cancer Immunol Immunother. (2004) 53:1146-52. doi: 10.1007/s00262-004-0556-2

94. Hirayama A, Kami K, Sugimoto M, Sugawara M, Toki N, Onozuka $\mathrm{H}$, et al. Quantitative metabolome profiling of colon and stomach cancer microenvironment by capillary electrophoresis time-of-flight mass spectrometry. Cancer Res. (2009) 69:4918-25. doi: 10.1158/0008-5472.CAN-08-4806

95. Urasaki Y, Heath L, Xu CW. Coupling of glucose deprivation with impaired histone H2B monoubiquitination in tumors. PLoS ONE. (2012) 7:e36775. doi: 10.1371/journal.pone.0036775

96. Ho PC, Bihuniak JD, Macintyre AN, Staron M, Liu X, Amezquita R, et al. Phosphoenolpyruvate is a metabolic checkpoint of anti-tumor T cell responses. Cell. (2015) 162:1217-28. doi: 10.1016/j.cell.2015.08.012

97. Chang CH, Qiu J, O'Sullivan D, Buck MD, Noguchi T, Curtis JD, et al. Metabolic competition in the tumor microenvironment is a driver of cancer progression. Cell. (2015) 162:1229-41. doi: 10.1016/j.cell.2015.08.016

98. Biswas SK. Metabolic reprogramming of immune cells in cancer progression. Immunity. (2015) 43:435-49. doi: 10.1016/j.immuni.2015.09.001

99. Kishton RJ, Sukumar M, Restifo NP. Metabolic regulation of T cell longevity and function in tumor immunotherapy. Cell Metab. (2017) 26:94-109. doi: 10.1016/j.cmet.2017.06.016

100. Wenes M, Shang M, Di Matteo M, Goveia J, Martin-Perez R, Serneels J, et al. Macrophage metabolism controls tumor blood vessel morphogenesis and metastasis. Cell Metab. (2016) 24:701-15. doi: 10.1016/j.cmet.2016.09.008

101. Zhao S, Torres A, Henry RA, Trefely S, Wallace M, Lee JV, et al. ATPcitrate lyase controls a glucose-to-acetate metabolic switch. Cell Rep. (2016) 17:1037-52. doi: 10.1016/j.celrep.2016.09.069

102. Keating SE, Zaiatz-Bittencourt V, Loftus RM, Keane C, Brennan K, Finlay DK, et al. Metabolic reprogramming supports IFN-gamma production by CD56bright NK cells. J Immunol. (2016) 196:2552-60. doi: 10.4049/jimmunol.1501783

103. Philip M, Fairchild L, Sun L, Horste EL, Camara S, Shakiba M, et al. Chromatin states define tumour-specific $\mathrm{T}$ cell dysfunction and reprogramming. Nature. (2017) 545:452-6. doi: 10.1038/nature22367

104. Schietinger A, Philip M, Krisnawan VE, Chiu EY, Delrow JJ, Basom RS, et al. Tumor-specific T cell dysfunction is a dynamic antigen-driven differentiation program initiated early during tumorigenesis. Immunity. (2016) 45:389-401. doi: 10.1016/j.immuni.2016.07.011

105. Assmann N, O’Brien KL, Donnelly RP, Dyck L, Zaiatz-Bittencourt V, Loftus RM, et al. Srebp-controlled glucose metabolism is essential for NK cell functional responses. Nat Immunol. (2017) 18:1197-206. doi: $10.1038 /$ ni.3838

106. Li D, Long W, Huang R, Chen Y, Xia M. 27-Hydroxycholesterol inhibits sterol regulatory element-binding protein 1 activation and hepatic lipid accumulation in mice. Obesity. (2018) 26:713-22. doi: 10.1002/oby.22130

107. Adams CM, Reitz J, De Brabander JK, Feramisco JD, Li L, Brown MS, et al. Cholesterol and 25-hydroxycholesterol inhibit activation of SREBPs by different mechanisms, both involving SCAP and Insigs. J Biol Chem. (2004) 279:52772-80. doi: 10.1074/jbc.M410302200

108. Michelet X, Dyck L, Hogan A, Loftus RM, Duquette D, Wei K, et al. Metabolic reprogramming of natural killer cells in obesity limits antitumor responses. Nat Immunol. (2018) 19:1330-40. doi: 10.1038/s41590-018-0251-7

109. Zelenay S, van der Veen AG, Bottcher JP, Snelgrove KJ, Rogers N, Acton $\mathrm{SE}$, et al. Cyclooxygenase-dependent tumor growth through evasion of immunity. Cell. (2015) 162:1257-70. doi: 10.1016/j.cell.2015.08.015 
110. Hangai S, Ao T, Kimura Y, Matsuki K, Kawamura T, Negishi H, et al. PGE2 induced in and released by dying cells functions as an inhibitory DAMP. Proc Natl Acad Sci USA. (2016) 113:3844-9. doi: 10.1073/pnas.160 2023113

111. Kalinski P. Regulation of immune responses by prostaglandin E2. J Immunol. (2012) 188:21-8. doi: 10.4049/jimmunol.1101029

112. Holt D, Ma X, Kundu N, Fulton A. Prostaglandin E(2) (PGE. (2)) suppresses natural killer cell function primarily through the PGE(2) receptor EP4. Cancer Immunol Immunother. (2011) 60:1577-86. doi: 10.1007/s00262-011-1064-9

113. Rabinovich GA, Gabrilovich D, Sotomayor EM. Immunosuppressive strategies that are mediated by tumor cells. Annu Rev Immunol. (2007) 25:267-96. doi: 10.1146/annurev.immunol.25.022106.141609

114. Balsamo M, Scordamaglia F, Pietra G, Manzini C, Cantoni C, Boitano $\mathrm{M}$, et al. Melanoma-associated fibroblasts modulate NK cell phenotype and antitumor cytotoxicity. Proc Natl Acad SciUSA. (2009) 106:20847-52. doi: 10.1073/pnas.0906481106

115. Mantovani A, Allavena P, Sica A, Balkwill F. Cancer-related inflammation. Nature. (2008) 454:436-44. doi: 10.1038/nature07205

116. Spaggiari GM, Capobianco A, Abdelrazik H, Becchetti F, Mingari MC, Moretta L. Mesenchymal stem cells inhibit natural killer-cell proliferation, cytotoxicity, and cytokine production: role of indoleamine 2,3-dioxygenase and prostaglandin E2. Blood. (2008) 111:1327-33. doi: 10.1182/blood-2007-02-074997

117. Galland S, Vuille J, Martin P, Letovanec I, Caignard A, Fregni G, et al. Tumor-derived mesenchymal stem cells use distinct mechanisms to block the activity of natural killer cell subsets. Cell Rep. (2017) 20:2891-905. doi: 10.1016/j.celrep.2017.08.089

118. Mao Y, Sarhan D, Steven A, Seliger B, Kiessling R, Lundqvist A. Inhibition of tumor-derived prostaglandin-e2 blocks the induction of myeloid-derived suppressor cells and recovers natural killer cell activity. Clin Cancer Res. (2014) 20:4096-106. doi: 10.1158/1078-0432.CCR-14-0635

119. Park A, Lee Y, Kim MS, Kang YJ, Park YJ, Jung H, et al. Prostaglandin E2 secreted by thyroid cancer cells contributes to immune escape through the suppression of natural killer (NK) cell cytotoxicity and NK cell differentiation. Front Immunol. (2018) 9:1859. doi: 10.3389/fimmu.2018.01859

120. Su Y, Huang X, Raskovalova T, Zacharia L, Lokshin A, Jackson E, et al. Cooperation of adenosine and prostaglandin E2 (PGE2) in amplification of cAMP-PKA signaling and immunosuppression. Cancer Immunol Immunother. (2008) 57:1611-23. doi: 10.1007/s00262-008-0494-5

121. Pietra G, Manzini C, Rivara S, Vitale M, Cantoni C, Petretto A, et al. Melanoma cells inhibit natural killer cell function by modulating the expression of activating receptors and cytolytic activity. Cancer Res. (2012) 72:1407-15. doi: 10.1158/0008-5472.CAN-11-2544

122. Ma X, Holt D, Kundu N, Reader J, Goloubeva O, Take Y, et al. A prostaglandin E (PGE) receptor EP4 antagonist protects natural killer cells from PGE2-mediated immunosuppression and inhibits breast cancer metastasis. Oncoimmunology. (2013) 2:e22647. doi: 10.4161/onci.22647

123. Li T, Zhang Q, Jiang Y, Yu J, Hu Y, Mou T, et al. Gastric cancer cells inhibit natural killer cell proliferation and induce apoptosis via prostaglandin E2. Oncoimmunology. (2016) 5:e1069936. doi: 10.1080/2162402X.2015.1069936

124. Frumento G, Rotondo R, Tonetti M, Damonte G, Benatti U, Ferrara GB. Tryptophan-derived catabolites are responsible for inhibition of $\mathrm{T}$ and natural killer cell proliferation induced by indoleamine 2,3-dioxygenase. $J$ Exp Med. (2002) 196:459-68. doi: 10.1084/jem.20020121

125. Yoshida N, Ino K, Ishida Y, Kajiyama H, Yamamoto E, Shibata K, et al. Overexpression of indoleamine 2,3-dioxygenase in human endometrial carcinoma cells induces rapid tumor growth in a mouse xenograft model. Clin Cancer Res. (2008) 14:7251-9. doi: 10.1158/1078-0432.CCR-08-0991

126. Della Chiesa M, Carlomagno S, Frumento G, Balsamo M, Cantoni $\mathrm{C}$, Conte $\mathrm{R}$, et al. The tryptophan catabolite L-kynurenine inhibits the surface expression of NKp46- and NKG2D-activating receptors and regulates NK-cell function. Blood. (2006) 108:4118-25. doi: 10.1182/blood-2006-03-006700

127. Folgiero V, Cifaldi L, Li Pira G, Goffredo BM, Vinti L, Locatelli F. TIM-3/Gal-9 interaction induces IFNgamma-dependent IDO1 expression in acute myeloid leukemia blast cells. J Hematol Oncol. (2015) 8:36. doi: 10.1186/s13045-015-0134-4

128. Vigano S, Alatzoglou D, Irving M, Menetrier-Caux C, Caux C, Romero P, et al. Targeting Adenosine in Cancer Immunotherapy to Enhance T-Cell Function. Front Immunol. (2019) 10:925. doi: 10.3389/fimmu.2019.00925

129. Bastid J, Regairaz A, Bonnefoy N, Dejou C, Giustiniani J, Laheurte C, et al. Inhibition of CD39 enzymatic function at the surface of tumor cells alleviates their immunosuppressive activity. Cancer Immunol Res. (2015) 3:254-65. doi: 10.1158/2326-6066.CIR-14-0018

130. Hausler SF, Montalban del Barrio I, Strohschein J, Chandran PA, Engel JB, Honig A, et al. Ectonucleotidases CD39 and CD73 on OvCA cells are potent adenosine-generating enzymes responsible for adenosine receptor 2A-dependent suppression of T cell function and NK cell cytotoxicity. Cancer Immunol Immunother. (2011) 60:1405-18. doi: 10.1007/s00262-011-1040-4

131. Hausler SF, Del Barrio IM, Diessner J, Stein RG, Strohschein J, Honig A, et al. Anti-CD39 and anti-CD73 antibodies A1 and 7G2 improve targeted therapy in ovarian cancer by blocking adenosine-dependent immune evasion. Am J Transl Res. (2014) 6:129-39.

132. Iannone R, Miele L, Maiolino P, Pinto A, Morello S. Adenosine limits the therapeutic effectiveness of anti-CTLA4 mAb in a mouse melanoma model. Am J Cancer Res. (2014) 4:172-81.

133. Ma SR, Deng WW, Liu JF, Mao L, Yu GT, Bu LL, et al. Blockade of adenosine $\mathrm{A} 2 \mathrm{~A}$ receptor enhances CD8 $(+) \mathrm{T}$ cells response and decreases regulatory $\mathrm{T}$ cells in head and neck squamous cell carcinoma. Mol Cancer. (2017) 16:99. doi: 10.1186/s12943-017-0665-0

134. Young A, Ngiow SF, Gao Y, Patch AM, Barkauskas DS, Messaoudene $\mathrm{M}$, et al. A2AR adenosine signaling suppresses natural killer cell maturation in the tumor microenvironment. Cancer Res. (2018) 78:1003-16. doi: 10.1158/0008-5472.CAN-17-2826

135. Petrova V, Annicchiarico-Petruzzelli M, Melino G, Amelio I. The hypoxic tumour microenvironment. Oncogenesis. (2018) 7:10. doi: 10.1038/s41389-017-0011-9

136. Sceneay J, Chow MT, Chen A, Halse HM, Wong CS, Andrews DM, et al. Primary tumor hypoxia recruits CD11b+/Ly6Cmed/Ly6G+ immune suppressor cells and compromises NK cell cytotoxicity in the premetastatic niche. Cancer Res. (2012) 72:3906-11. doi: 10.1158/0008-5472.CAN-11-3873

137. Fink T, Ebbesen P, Koppelhus U, Zachar V. Natural killer cell-mediated basal and interferon-enhanced cytotoxicity against liver cancer cells is significantly impaired under in vivo oxygen conditions. Scand J Immunol. (2003) 58:60712. doi: 10.1111/j.1365-3083.2003.01347.x

138. Balsamo M, Manzini C, Pietra G, Raggi F, Blengio F, Mingari MC, et al. Hypoxia downregulates the expression of activating receptors involved in NK-cell-mediated target cell killing without affecting ADCC. Eur J Immunol. (2013) 43:2756-64. doi: 10.1002/eji.201343448

139. Sarkar S, Germeraad WT, Rouschop KM, Steeghs EM, van Gelder M, Bos GM, et al. Hypoxia induced impairment of NK cell cytotoxicity against multiple myeloma can be overcome by IL-2 activation of the NK cells. PLoS ONE. (2013) 8:e64835. doi: 10.1371/journal.pone.0064835

140. Xie H, Hanai J, Ren JG, Kats L, Burgess K, Bhargava P, et al. Targeting lactate dehydrogenase-a inhibits tumorigenesis and tumor progression in mouse models of lung cancer and impacts tumor-initiating cells. Cell Metab. (2014) 19:795-809. doi: 10.1016/j.cmet.2014.03.003

141. Husain Z, Huang Y, Seth P, Sukhatme VP. Tumor-derived lactate modifies antitumor immune response: effect on myeloid-derived suppressor cells and NK cells. J Immunol. (2013) 191:1486-95. doi: 10.4049/jimmunol. 1202702

142. Husain Z, Seth P, Sukhatme VP. Tumor-derived lactate and myeloidderived suppressor cells: linking metabolism to cancer immunology. Oncoimmunology. (2013) 2:e26383. doi: 10.4161/onci.26383

143. Harmon C, Robinson MW, Hand F, Almuaili D, Mentor K, Houlihan DD, et al. Lactate-mediated acidification of tumor microenvironment induces apoptosis of liver-resident NK cells in colorectal liver metastasis. Cancer Immunol Res. (2019) 7:335-46. doi: 10.1158/2326-6066.CIR-18-0481

144. Long Y, Gao Z, Hu X, Xiang F, Wu Z, Zhang J, et al. Downregulation of MCT4 for lactate exchange promotes the cytotoxicity of NK cells in breast carcinoma. Cancer Med. (2018) 7:4690-700. doi: 10.1002/ cam4.1713 
145. Molgora M, Bonavita E, Ponzetta A, Riva F, Barbagallo M, Jaillon S, et al. IL$1 \mathrm{R} 8$ is a checkpoint in NK cells regulating anti-tumour and anti-viral activity. Nature. (2017) 551:110-14. doi: 10.1038/nature24293

146. Beldi-Ferchiou A, Caillat-Zucman S. Control of NK cell activation by immune checkpoint molecules. Int J Mol Sci. (2017) 18:E2129. doi: 10.3390/ijms18102129

147. Kim N, Kim HS. Targeting checkpoint receptors and molecules for therapeutic modulation of natural killer cells. Front Immunol. (2018) 9:2041. doi: 10.3389/fimmu.2018.02041

148. Vitale M, Cantoni C, Pietra G, Mingari MC, Moretta L. Effect of tumor cells and tumor microenvironment on NK-cell function. Eur J Immunol. (2014) 44:1582-92. doi: 10.1002/eji.201344272

149. Parihar R, Dierksheide J, Hu Y, Carson WE. IL-12 enhances the natural killer cell cytokine response to Ab-coated tumor cells. J Clin Invest. (2002) 110:983-92. doi: 10.1172/JCI0215950

150. Robertson MJ, Kirkwood JM, Logan TF, Koch KM, Kathman S, Kirby LC, et al. A dose-escalation study of recombinant human interleukin-18 using two different schedules of administration in patients with cancer. Clin Cancer Res. (2008) 14:3462-9. doi: 10.1158/1078-0432.CCR-07-4740

151. Simpkins F, Flores A, Chu C, Berek JS, Lucci J 3rd, Murray S, et al. Chemoimmunotherapy using pegylated liposomal Doxorubicin and interleukin-18 in recurrent ovarian cancer: a phase I dose-escalation study. Cancer Immunol Res. (2013) 1:168-78. doi: 10.1158/2326-6066.CIR-13-0098

152. Han KP, Zhu X, Liu B, Jeng E, Kong L, Yovandich JL, et al. IL15:IL-15 receptor alpha superagonist complex: high-level co-expression in recombinant mammalian cells, purification and characterization. Cytokine. (2011) 56:804-10. doi: 10.1016/j.cyto.2011.09.028

153. Thompson JA, Curti BD, Redman BG, Bhatia S, Weber JS, Agarwala SS, et al. Phase I study of recombinant interleukin-21 in patients with metastatic melanoma and renal cell carcinoma. J Clin Oncol. (2008) 26:20349. doi: 10.1200/JCO.2007.14.5193

154. Petrella TM, Tozer R, Belanger K, Savage KJ, Wong R, Smylie M, et al. Interleukin-21 has activity in patients with metastatic melanoma: a phase II study. J Clin Oncol. (2012) 30:3396-401. doi: 10.1200/JCO.2011.40.0655

155. Grunwald V, Desar IM, Haanen J, Fiedler W, Mouritzen U, Olsen MW, et al. A phase I study of recombinant human interleukin-21 (rIL-21) in combination with sunitinib in patients with metastatic renal cell carcinoma (RCC). Acta Oncol. (2011) 50:121-6. doi: 10.3109/0284186X.2010.509104

156. Miller JS, Morishima C, McNeel DG, Patel MR, Kohrt HEK, Thompson JA, et al. A first-in-human phase I study of subcutaneous outpatient recombinant human IL15 (rhIL15) in adults with advanced solid tumors. Clin Cancer Res. (2018) 24:1525-35. doi: 10.1158/1078-0432.CCR-17-2451

157. Xu W, Jones M, Liu B, Zhu X, Johnson CB, Edwards AC, et al. Efficacy and mechanism-of-action of a novel superagonist interleukin15: interleukin-15 receptor alphaSu/Fc fusion complex in syngeneic murine models of multiple myeloma. Cancer Res. (2013) 73:3075-86. doi: 10.1158/0008-5472.CAN-12-2357

158. Rosario M, Liu B, Kong L, Collins LI, Schneider SE, Chen X, et al. The IL-15-based ALT-803 complex enhances FcgammaRIIIa-triggered NK cell responses and in vivo clearance of B cell lymphomas. Clin Cancer Res. (2016) 22:596-608. doi: 10.1158/1078-0432.CCR-15-1419

159. Romee R, Cooley S, Berrien-Elliott MM, Westervelt P, Verneris MR, Wagner JE, et al. First-in-human phase 1 clinical study of the IL-15 superagonist complex ALT-803 to treat relapse after transplantation. Blood. (2018) 131:2515-27. doi: 10.1182/blood-2017-12-823757

160. Margolin K, Morishima C, Velcheti V, Miller JS, Lee SM, Silk AW, et al. Phase I trial of ALT-803, a novel recombinant IL15 complex, in patients with advanced solid tumors. Clin Cancer Res. (2018) 24:5552-61. doi: 10.1158/1078-0432.CCR-18-0945

161. Wrangle JM, Velcheti V, Patel MR, Garrett-Mayer E, Hill EG, Ravenel JG, et al. ALT-803, an IL-15 superagonist, in combination with nivolumab in patients with metastatic non-small cell lung cancer: a nonrandomised, open-label, phase 1b trial. Lancet Oncol. (2018) 19:694-704. doi: 10.1016/S1470-2045(18)30148-7

162. Groh V, Wu J, Yee C, Spies T. Tumour-derived soluble MIC ligands impair expression of NKG2D and T-cell activation. Nature. (2002) 419:734-8. doi: $10.1038 /$ nature 01112
163. Lu S, Zhang J, Liu D, Li G, Staveley-O'Carroll KF, Li Z, et al. Nonblocking monoclonal antibody targeting soluble MIC revamps endogenous innate and adaptive antitumor responses and eliminates primary and metastatic tumors. Clin Cancer Res. (2015) 21:4819-30. doi: 10.1158/1078-0432.CCR-15-0845

164. Zhang J, Liu D, Li G, Staveley-O'Carroll KF, Graff JN, Li Z, et al. Antibodymediated neutralization of soluble MIC significantly enhances CTLA4 blockade therapy. Sci Adv. (2017) 3:e1602133. doi: 10.1126/sciadv.1602133

165. Brandetti E, Veneziani I, Melaiu O, Pezzolo A, Castellano A, Boldrini R, et al. MYCN is an immunosuppressive oncogene dampening the expression of ligands for NK-cell-activating receptors in human high-risk neuroblastoma. Oncoimmunology. (2017) 6:e1316439. doi: 10.1080/2162402X.2017.1316439

166. Handgretinger R, Anderson K, Lang P, Dopfer R, Klingebiel T, Schrappe $\mathrm{M}$, et al. A phase I study of human/mouse chimeric antiganglioside GD2 antibody ch14.18 in patients with neuroblastoma. Eur J Cancer. (1995) 31A:261-7. doi: 10.1016/0959-8049(94)00413-Y

167. Richards RM, Sotillo E, Majzner RG. CAR T cell therapy for neuroblastoma. Front Immunol. (2018) 9:2380. doi: 10.3389/fimmu.2018.02380

168. Vey N, Karlin L, Sadot-Lebouvier S, Broussais F, Berton-Rigaud D, Rey J, et al. A phase 1 study of lirilumab (antibody against killer immunoglobulin-like receptor antibody KIR2D; IPH2102) in patients with solid tumors and hematologic malignancies. Oncotarget. (2018) 9:17675-88. doi: 10.18632/oncotarget.24832

169. He Y, Liu S, Mattei J, Bunn PA Jr, Zhou C, Chan D. The combination of antiKIR monoclonal antibodies with anti-PD-1/PD-L1 monoclonal antibodies could be a critical breakthrough in overcoming tumor immune escape in NSCLC. Drug Des Devel Ther. (2018) 12:981-6. doi: 10.2147/DDDT. S163304

170. Liu Y, Cheng Y, Xu Y, Wang Z, Du X, Li C, et al. Increased expression of programmed cell death protein 1 on NK cells inhibits NK-cell-mediated antitumor function and indicates poor prognosis in digestive cancers. Oncogene. (2017) 36:6143-53. doi: 10.1038/onc.2017.209

171. Sanseviero E, O'Brien EM, Karras JR, Shabaneh TB, Aksoy BA, Xu W, et al. Anti-CTLA-4 activates intratumoral NK cells and combined with IL15/IL15Ralpha complexes enhances tumor control. Cancer Immunol Res. (2019) 7:1371-80. doi: 10.1158/2326-6066.CIR-18-0386

172. Zhang Q, Bi J, Zheng X, Chen Y, Wang H, Wu W, et al. Blockade of the checkpoint receptor TIGIT prevents NK cell exhaustion and elicits potent anti-tumor immunity. Nat Immunol. (2018) 19:723-32. doi: 10.1038/s41590-018-0132-0

173. Blake SJ, Dougall WC, Miles JJ, Teng MW, Smyth MJ. Molecular pathways: targeting CD96 and TIGIT for cancer immunotherapy. Clin Cancer Res. (2016) 22:5183-8. doi: 10.1158/1078-0432.CCR-16-0933

174. Cifaldi L, Doria M, Cotugno N, Zicari S, Cancrini C, Palma P, et al. DNAM1 activating receptor and its ligands: how do viruses affect the NK cellmediated immune surveillance during the various phases of infection? Int J Mol Sci. (2019) 20:E3715. doi: 10.3390/ijms20153715

175. Stojanovic A, Cerwenka A. Checkpoint inhibition: NK cells enter the scene. Nat Immunol. (2018) 19:650-2. doi: 10.1038/s41590-018-0142-y

176. Xu F, Sunderland A, Zhou Y, Schulick RD, Edil BH, Zhu Y. Blockade of CD112R and TIGIT signaling sensitizes human natural killer cell functions. Cancer Immunol Immunother. (2017) 66:1367-75. doi: 10.1007/s00262-017-2031-x

177. Blake SJ, Stannard K, Liu J, Allen S, Yong MC, Mittal D, et al. Suppression of metastases using a new lymphocyte checkpoint target for cancer immunotherapy. Cancer Discov. (2016) 6:446-59. doi: 10.1158/2159-8290.CD-15-0944

178. da Silva IP, Gallois A, Jimenez-Baranda S, Khan S, Anderson AC, Kuchroo VK, et al. Reversal of NK-cell exhaustion in advanced melanoma by Tim-3 blockade. Cancer Immunol Res. (2014) 2:410-22. doi: 10.1158/2326-6066.CIR-13-0171

179. Turini M, Chames P, Bruhns P, Baty D, Kerfelec B. A FcgammaRIIIengaging bispecific antibody expands the range of HER2-expressing breast tumors eligible to antibody therapy. Oncotarget. (2014) 5:5304-19. doi: 10.18632/oncotarget.2093

180. Vallera DA, Zhang B, Gleason MK, Oh S, Weiner LM, Kaufman DS, et al. Heterodimeric bispecific single-chain variable-fragment antibodies against EpCAM and CD16 induce effective antibody-dependent cellular cytotoxicity 
against human carcinoma cells. Cancer Biother Radiopharm. (2013) 28:27482. doi: $10.1089 / \mathrm{cbr} .2012 .1329$

181. Oberg HH, Kellner C, Gonnermann D, Sebens S, Bauerschlag D, Gramatzki $M$, et al. Tribody [(HER2)2xCD16] is more effective than trastuzumab in enhancing gammadelta $\mathrm{T}$ cell and natural killer cell cytotoxicity against HER2-expressing cancer cells. Front Immunol. (2018) 9:814. doi: 10.3389/fimmu.2018.00814

182. Gilman AL, Ozkaynak MF, Matthay KK, Krailo M, Yu AL, Gan J, et al. Phase I study of ch14.18 with granulocyte-macrophage colonystimulating factor and interleukin-2 in children with neuroblastoma after autologous bone marrow transplantation or stem-cell rescue: a report from the Children's Oncology Group. J Clin Oncol. (2009) 27:85-91. doi: 10.1200/JCO.2006.10.3564

183. Simon T, Hero B, Faldum A, Handgretinger R, Schrappe M, Niethammer D, et al. Consolidation treatment with chimeric anti-GD2-antibody ch14.18 in children older than 1 year with metastatic neuroblastoma. J Clin Oncol. (2004) 22:3549-57. doi: 10.1200/JCO.2004.08.143

184. Vincent M, Quemener A, Jacques Y. Antitumor activity of an immunocytokine composed of an anti-GD2 antibody and the IL-15 superagonist RLI. Oncoimmunology. (2013) 2:e26441. doi: $10.4161 /$ onci.26441

185. Fallon J, Tighe R, Kradjian G, Guzman W, Bernhardt A, Neuteboom B, et al. The immunocytokine NHS-IL12 as a potential cancer therapeutic. Oncotarget. (2014) 5:1869-84. doi: 10.18632/oncotarget.1853

186. Klein C, Waldhauer I, Nicolini VG, Freimoser-Grundschober A, Nayak T, Vugts DJ, et al. Cergutuzumab amunaleukin (CEA-IL2v), a CEAtargeted IL-2 variant-based immunocytokine for combination cancer immunotherapy: overcoming limitations of aldesleukin and conventional IL-2-based immunocytokines. Oncoimmunology. (2017) 6:e1277306. doi: $10.1080 / 2162402 X .2016 .1277306$

187. Hu W, Wang G, Huang D, Sui M, Xu Y. Cancer immunotherapy based on natural killer cells: current progress and new opportunities. Front Immunol. (2019) 10:1205. doi: 10.3389/fimmu.2019.01205

188. Fang F, Xiao W, Tian Z. NK cell-based immunotherapy for cancer. Semin Immunol. (2017) 31:37-54. doi: 10.1016/j.smim.2017.07.009

189. Abel AM, Yang C, Thakar MS, Malarkannan S. Natural killer cells: development, maturation, and clinical utilization. Front Immunol. (2018) 9:1869. doi: 10.3389/fimmu.2018.01869

190. Ruggeri L, Capanni M, Casucci M, Volpi I, Tosti A, Perruccio K, et al. Role of natural killer cell alloreactivity in HLA-mismatched hematopoietic stem cell transplantation. Blood. (1999) 94:333-9. doi: 10.1182/blood.V94.1.333.413a31_333_339

191. Miller JS, Soignier Y, Panoskaltsis-Mortari A, McNearney SA, Yun GH, Fautsch SK, et al. Successful adoptive transfer and in vivo expansion of human haploidentical NK cells in patients with cancer. Blood. (2005) 105:3051-7. doi: 10.1182/blood-2004-07-2974

192. Curti A, Ruggeri L, D’Addio A, Bontadini A, Dan E, Motta MR, et al. Successful transfer of alloreactive haploidentical KIR ligand-mismatched natural killer cells after infusion in elderly high risk acute myeloid leukemia patients. Blood. (2011) 118:3273-9. doi: 10.1182/blood-2011-01-329508

193. Rezvani K, Rouce RH. The application of natural killer cell immunotherapy for the treatment of cancer. Front Immunol. (2015) 6:578. doi: 10.3389/fimmu. 2015.00578

194. Guillerey C, Huntington ND, Smyth MJ. Targeting natural killer cells in cancer immunotherapy. Nat Immunol. (2016) 17:1025-36. doi: $10.1038 /$ ni. 3518

195. Veluchamy JP, Kok N, van der Vliet HJ, Verheul HMW, de Gruijl TD, Spanholtz J. The rise of allogeneic natural killer cells as a platform for cancer immunotherapy: recent innovations and future developments. Front Immunol. (2017) 8:631. doi: 10.3389/fimmu.2017.00631

196. Cichocki F, Valamehr B, Bjordahl R, Zhang B, Rezner B, Rogers $\mathrm{P}$, et al. GSK3 inhibition drives maturation of NK cells and enhances their antitumor activity. Cancer Res. (2017) 77:5664-75. doi: 10.1158/0008-5472.CAN-17-0799

197. Cifaldi L, Locatelli F, Marasco E, Moretta L, Pistoia V. Boosting natural killer cell-based immunotherapy with anticancer drugs: a perspective.
Trends Mol Med. (2017) 23:1156-75. doi: 10.1016/j.molmed.2017. 10.002

198. Rezvani K. Adoptive cell therapy using engineered natural killer cells. Bone Marrow Transplant. (2019) 54(Suppl 2):785-8. doi: 10.1038/s41409-019-0601-6

199. Zhang C, Oberoi P, Oelsner S, Waldmann A, Lindner A, Tonn T, et al. Chimeric antigen receptor-engineered NK-92 cells: an off-theshelf cellular therapeutic for targeted elimination of cancer cells and induction of protective antitumor immunity. Front Immunol. (2017) 8:533. doi: $10.3389 /$ fimmu.2017.00533

200. Oberschmidt O, Kloess S, Koehl U. Redirected primary human chimeric antigen receptor natural killer cells as an "off-the-shelf immunotherapy" for improvement in cancer treatment. Front Immunol. (2017) 8:654. doi: $10.3389 /$ fimmu.2017.00654

201. Li Y, Hermanson DL, Moriarity BS, Kaufman DS. Human iPSCderived natural killer cells engineered with chimeric antigen receptors enhance anti-tumor activity. Cell Stem Cell. (2018) 23:181-92 e185. doi: 10.1016/j.stem.2018.06.002

202. Jochems C, Hodge JW, Fantini M, Fujii R, Morillon YM 2nd, Greiner JW, et al. An NK cell line (haNK) expressing high levels of granzyme and engineered to express the high affinity CD16 allele. Oncotarget. (2016) 7:86359-373. doi: 10.18632/oncotarget.13411

203. Chen X, Han J, Chu J, Zhang L, Zhang J, Chen C, et al. A combinational therapy of EGFR-CAR NK cells and oncolytic herpes simplex virus 1 for breast cancer brain metastases. Oncotarget. (2016) 7:27764-77. doi: 10.18632/oncotarget. 8526

204. Schonfeld K, Sahm C, Zhang C, Naundorf S, Brendel C, Odendahl M, et al. Selective inhibition of tumor growth by clonal NK cells expressing an ErbB2/HER2-specific chimeric antigen receptor. Mol Ther. (2015) 23:330-8. doi: 10.1038/mt.2014.219

205. Zhang C, Burger MC, Jennewein L, Genssler S, Schonfeld K, Zeiner P, et al. ErbB2/HER2-specific NK cells for targeted therapy of glioblastoma. J Natl Cancer Inst. (2015) 108. doi: 10.1093/jnci/djv375

206. Murakami T, Nakazawa T, Natsume A, Nishimura F, Nakamura M, Matsuda $\mathrm{R}$, et al. Novel human NK cell line carrying CAR targeting EGFRvIII induces antitumor effects in glioblastoma cells. Anticancer Res. (2018) 38:5049-56. doi: 10.21873/anticanres.12824

207. Esser R, Muller T, Stefes D, Kloess S, Seidel D, Gillies SD, et al. NK cells engineered to express a GD2 -specific antigen receptor display built-in ADCC-like activity against tumour cells of neuroectodermal origin. J Cell Mol Med. (2012) 16:569-81. doi: 10.1111/j.1582-4934.2011. 01343.x

208. Sahm C, Schonfeld K, Wels WS. Expression of IL-15 in NK cells results in rapid enrichment and selective cytotoxicity of gene-modified effectors that carry a tumor-specific antigen receptor. Cancer Immunol Immunother. (2012) 61:1451-61. doi: 10.1007/s00262-012-1212-x

209. Jong AY, Wu CH, Li J, Sun J, Fabbri M, Wayne AS, et al. Largescale isolation and cytotoxicity of extracellular vesicles derived from activated human natural killer cells. J Extracell Vesicles. (2017) 6:1294368. doi: $10.1080 / 20013078.2017 .1294368$

210. Zhu L, Oh JM, Gangadaran P, Kalimuthu S, Baek SH, Jeong SY, et al. Targeting and therapy of glioblastoma in a mouse model using exosomes derived from natural killer cells. Front Immunol. (2018) 9:824. doi: $10.3389 /$ fimmu.2018.00824

Conflict of Interest: The authors declare that the research was conducted in the absence of any commercial or financial relationships that could be construed as a potential conflict of interest.

Copyright (0) 2020 Melaiu, Lucarini, Cifaldi and Fruci. This is an open-access article distributed under the terms of the Creative Commons Attribution License (CC BY). The use, distribution or reproduction in other forums is permitted, provided the original author(s) and the copyright owner(s) are credited and that the original publication in this journal is cited, in accordance with accepted academic practice. No use, distribution or reproduction is permitted which does not comply with these terms. 